University of South Florida

DIGITAL COMMONS

Digital Commons @ University of

@ UNIVERSITY OF SOUTH FLORIDA

South Florida

USF Tampa Graduate Theses and Dissertations

USF Graduate Theses and Dissertations

7-8-2010

\title{
Influence of Misperceptions About Gay Affluence on Support for Pro-Gay Legal Reform
}

Vanessa E. Hettinger

University of South Florida

Follow this and additional works at: https://digitalcommons.usf.edu/etd

Part of the American Studies Commons

\section{Scholar Commons Citation}

Hettinger, Vanessa E., "Influence of Misperceptions About Gay Affluence on Support for Pro-Gay Legal Reform" (2010). USF Tampa Graduate Theses and Dissertations.

https://digitalcommons.usf.edu/etd/1657

This Thesis is brought to you for free and open access by the USF Graduate Theses and Dissertations at Digital Commons @ University of South Florida. It has been accepted for inclusion in USF Tampa Graduate Theses and Dissertations by an authorized administrator of Digital Commons @ University of South Florida. For more information, please contact digitalcommons@usf.edu. 
Influence of Misperceptions About Gay Affluence on Support for Pro-Gay Legal Reform

by

Vanessa E. Hettinger

A thesis submitted in partial fulfillment

of the requirements for the degree of

Master of Arts

Department of Psychology

College of Arts and Sciences

University of South Florida

Major Professor: Joseph Vandello, Ph. D.

Jennifer Bosson, Ph. D.

Russell Johnson, Ph. D.

Date of Approval:

July 8th, 2010

Keywords: Heterosexism, Gay Rights, Positive Stereotypes, Underdog Support, Law

(C) Copyright 2010, Vanessa E. Hettinger 
Table of Contents

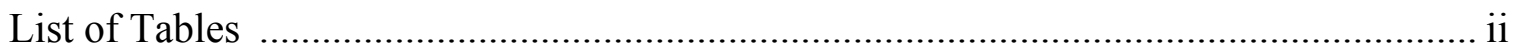

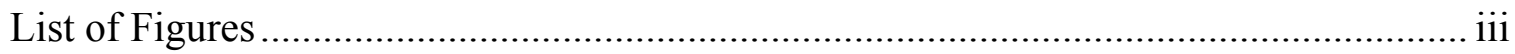

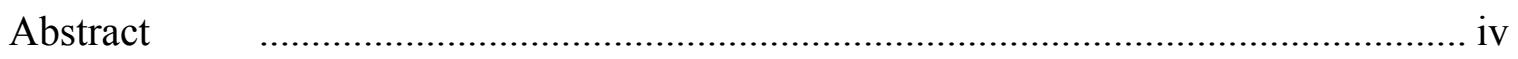

Introduction

Support for the Underdog ...........................................................................4

Negative Reactions to Advantaged Targets - Envy or Resentment? ......................5

Positive Stereotypes as a System Justification Strategy …..................................

Pilot Research .......................................................................................... 10

Overview of Proposal and Hypotheses ........................................................... 12

Methods

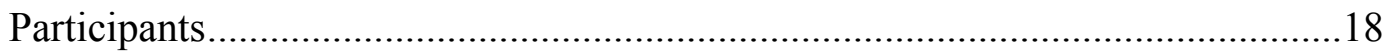

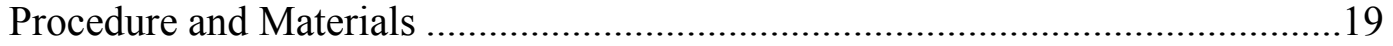

Relative / Own Affluence Questionnaires ..............................................20

Character Beliefs Questionnaire .........................................................21

Protestant Work Ethic Scale ................................................................22

Just World Beliefs ............................................................................22

Amnestic and Positive-Stereotypic Heterosexism Subscales ..................23

Homophobia Scale ............................................................................24

Legal Reform Questionnaire........................................................24

Results

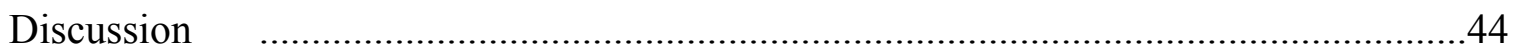

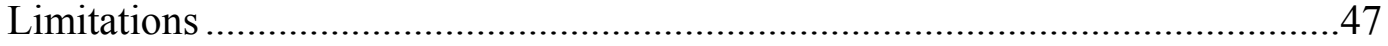

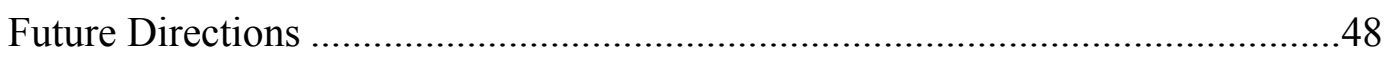

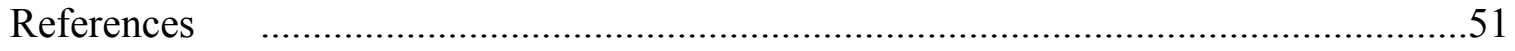

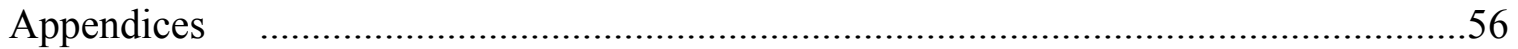

Appendix A: Informed Consent Statements / Optional Credit Instructions ...........57

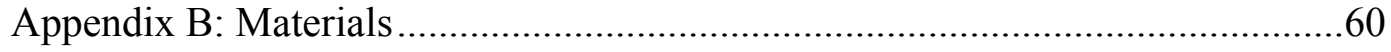

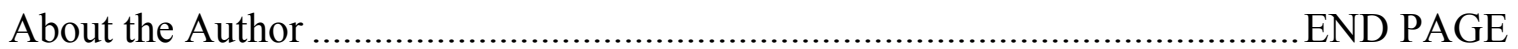




\section{List of Tables}

Table 1 Demographics, by Sample

Table 2A Regressing Support on Perceptions of Gay Wealth (Combined Sample)

Table 2B Regressing Support on Perceptions of Gay Wealth (Non-Student Sample)

Table 3 Regressing Support on Perceptions of Gay Wealth and

Participants' Own Wealth (Combined Sample)....

Table 4 Re-analysis: Using Wealth Difference Variable in Place of

Participant Wealth (Combined Sample) .35

Table 5 Regressing Support on Perceptions of Gay Wealth and Character Beliefs (Non-Student Sample) .............................................................36

Table 6A Regressing Support on Perceptions of Gay Wealth and Just World Beliefs (Combined Sample)

Table 6B Re-analysis, Adding Positive Stereotypic Heterosexism to the Model (Combined Sample)....

Table 7A Bivariate Correlations Among Variables of Interest in Combined

Sample.

Table 7B Bivariate Correlations Among Variables of Interest in Non-Student Sample. 


\section{List of Figures}

Figure 1. Support as a function of affluence perceptions, separated by sample.....

Figure 2. Support as a function of affluence and character perceptions (nonstudent sample)

Figure 3. Support as a function of affluence perceptions and just world belief (combined sample)........ 
Influence of Misperceptions About Gay Affluence on Support for Pro-Gay Legal Reform

\title{
Vanessa E. Hettinger
}

\begin{abstract}
The deleterious impact of negative stereotypes toward gays has been established, but less thoroughly examined are the potentially harmful effects that positive stereotypes may carry. Gay Americans lack multiple legal rights enjoyed by heterosexual citizens, yet many people do not see gays as a genuinely disadvantaged group. One possible reason for this is the popular misconception that gays are wealthier than the average American. Drawing on previous research regarding popular support for underdogs, it was predicted that, to the extent people endorsed the conception of gay affluence, they would be less likely to support legal reform benefiting gays. This hypothesis was supported: after controlling for overall homophobia and religiosity, perceiving gays as wealthy negatively predicted support for gay rights. This project also explored what emotional or cognitive mechanisms might influence the predicted relationship. Support was found for both resentment and system justification motivations as potential contributors to the effect.
\end{abstract}




\section{Introduction}

There are many stereotypes associated with homosexuality, and these have been the subject of a great deal of research. For many of these stereotypes, the harmfulness is obvious, whereas some appear to be more innocuous. One such seemingly innocuous stereotype is what has been referred to as 'the myth of gay affluence' (Badgett, 1998). I emphasize the word 'myth', because the total picture about differences in economic status between heterosexuals and gays is actually much more complex.

For instance, according to an examination by the Williams Institute using census data from 2000 and 2005, it is true that gay couples are significantly less likely to have children than heterosexual married couples, and significantly less likely to have a 'single earner' arrangement in their households, and these factors do lead to a significant positive difference in average household income when comparing all same-sex cohabitating couples to all heterosexual married couples (Romero, Baumle, Badgett \& Gates, 2007). However, for those same-sex couples who are raising children, their household income is actually significantly lower than that of heterosexual married couples. As of the time of their examination, $20 \%$ of same-sex couples in the U.S. were raising children under the age of 18 (compared with about half of heterosexual married couples). That percentage is only likely to increase over time.

Furthermore, when examining the average income of the individuals within the couples described above, results are even more complicated. Individually, men in samesex couples on average make significantly less than heterosexual married men. Women 
in same-sex couples on average make significantly more than heterosexual married women, but less than men in either category. To put this difference in context, census data which includes all year-round full time workers indicates an average income for women which is nearly identical to that of lesbians in same-sex couples (Weinberg, 2004). Thus, it is much more likely that any apparent economic advantage of lesbians over heterosexual married women is due to the difference in opting for single-earner arrangements mentioned above. The average income for all full time working men was approximately equal to that of heterosexual married men - again, significantly higher than that of men in same-sex couples. ${ }^{1}$

These comparisons, based solely on income, do not even take into account the myriad additional economic disadvantages facing gay couples relative to heterosexual married couples. A recent examination by The New York Times estimated the 'lifetime cost of being gay' to range from $\$ 40,000$ to $\$ 400,000$. Yet, despite the economic and racial $^{2}$ diversity of the gay and lesbian community, the image most associated with the word 'gay' is that of the wealthy, white gay man. This image is consistently reinforced by popular media (Gross, 2001), and even leveraged by presumably gay-friendly activists themselves in order to convince corporate entities to shift their business models and/or marketing strategies to accommodate gay consumers (Soule, 2006). ${ }^{3}$

\footnotetext{
${ }^{1}$ What we do not have here, unfortunately, is a reliable measure of average income for uncoupled gays and lesbians.

${ }^{2}$ According to 2000 census data, same-sex couples are actually proportionally more likely to be non-white than heterosexual married couples.

${ }^{3}$ Consider, for instance, the following claim in the 'About CMI' section of the Community Marketing, Inc. (a gay owned and operated specialty market research company): "The facts are plain: gay men and lesbians travel more, own more homes and cars, spend more on electronics, and have the largest amount of disposable income of any niche market.” (Available at: http://www.communitymarketinginc.com/
} 
This misportrayal of the bulk of the gay community has real consequences, however, in the realm of legal advocacy for gay rights. Citing an outrageous statistic reporting that the average gay household earns twice as much as the national average, in 1994, law Professor Joseph Broadus testified before Congress in argument against the passage of the Employment Non-Discrimination Act (ENDA) claiming that gays are an 'elite' group and as such do not need 'special civil rights legislation'. Though the bill has been reintroduced almost every year since then, fifteen years later it still has yet to become law.

Supreme Court Justice Antonin Scalia argued in his dissenting opinion in Romer v. Evans (1996) that gays' higher discretionary income granted them disproportionate political power, justifying Colorado voters in amending their constitution to preemptively bar any legislation aimed at protecting LGBT citizens. While this view fortunately did not win the day, similar rhetoric has surfaced in lower court decisions considering whether homosexuality should be considered a 'suspect classification' for the purposes of deciding the constitutionality of legislation aimed at or disproportionately affecting gays. This misportrayal is especially ironic considering the fact that early exposure to sexual orientation discrimination may actually be related to lower educational achievement for homosexuals, which in turn negatively impacts subsequent income potential (Barrett, Pollack \& Tilden, 2002).

I will argue, furthermore, that the popularized image of gay people as rich, white men may have an impact on the sympathy the general public feels for gays, and their

about.php). See also: The Gay Agenda: http://www.gayagenda.com/2008/08/as-straight-finance-walksgay-money-talks/; Parents, Families and Friends of Lesbians and Gays: http://community.pflag.org/Page .aspx?pid=322; and the Human Rights Campaign: http://www hrc.org/issues/4841.htm for similar claims. 
inclination to support various pro-gay legal reforms. Thus, this misperception of gays as affluent may have an effect not only at the level of legislative hearings and court decisions, but also at the level of grass-roots protests and referenda. Considering the current political climate in which judges often face strong criticism for progressive decisions that 'get ahead of popular opinion', a misconception that results in lower public support for gays could have crippling effects on the movement. In the following sections, I will discuss several lines of research, each of which could shed some light on why this hypothesized relationship between a public image of wealth and reduced popular support might exist.

\section{Support for the Underdog}

In a series of four studies, Vandello, Goldschmied, and Richards (2007) examined the tendency to support a perceived 'underdog'. The effect was robust and manipulable, suggesting that the higher levels of support observed in participants for entities portrayed as underdogs could not merely be attributed either to prior familiarity with or objective attributions about the depicted entities, but rather was a result of the underdog portrayal itself. Underdog status could be established either by presenting a stark comparison of the two entities' previous history of success, or even more subtly by making the entities appear larger or smaller by altering the scale and perspective of their relative representations on a map. In these situations, the entity depicted as smaller or having a lower expectation of success evoked greater levels of support from participants.

These initial studies still left open the question, however, of what exactly was required for an entity to be considered an underdog. In a fourth study, they demonstrated that low expectation for success was perhaps a necessary condition, but not always a 
sufficient one. Additionally, the purported underdog must be seen as materially

disadvantaged in some way. If the entity with lower expectations for success was also portrayed as having higher resources than the competition, support for that entity did not increase as in the other studies. The authors theorize about why elimination of the effect occurred:

We believe underdogs are supported because they are seen as disadvantaged [...which] arouses a sense of injustice in most people $[\ldots$ but $w]$ hen those with low expectations have ample resources, it is much less clear where the injustice lies, or if an injustice even exists. (Vandello et al, 2007).

Is material disadvantage merely a definitional prerequisite one must meet in order to reap the popular-support benefits of underdog status, or is there something else going on? Specifically, does the presentation of a would-be 'underdog' as someone with high resources bring about a negative reaction within the observer which conflicts with and effectively counteracts the urge to give that entity support? Or is the observer's support for the underdog an involuntary (and perhaps undesired) reaction to inequality, from which the counterbalancing effect of the information of relative resources relieves him? Negative Reactions to Advantaged Targets - Envy or Resentment?

Brigham, Kelso, Jackson and Smith (1997) discovered a positive relationship between participants' feelings of envy for a hypothetical target who was portrayed as having some sort of advantage relative to the participant, and feelings of schadenfreude when participants' were given information about the target's subsequent failure. Salovey and Rodin (1984) also found that social-comparison jealousy resulted in lower character 
evaluations of a target person who was portrayed as successful relative to the participant. This may suggest that feelings of envy drive the proposed negative correlation between perceptions of gay affluence and support for pro-gay legal reform. Indeed, there have been some studies indicating that anti-gay sentiment is higher in people with lower income (see e.g. Battle \& Lemelle, 2002).

Feather and Sherman (2002) on the other hand suggest that it is not envy, but rather resentment that causes negative reactions to advantaged targets. The authors distinguish resentment from envy by pointing out that resentment has "more of a public, sanctioned character" because it is more often tied to perceptions about fairness or deservingness than is envy. Whereas envy, they argue, arises from a feeling of anger at one's own relative disadvantage, resentment stems from a sense of indignation on perceiving that another's relative advantage is undeserved. In their study, participants' own GPA did predict how much envy they felt for the academically-advantaged target, and envy was significantly related to a desire to see the target person 'cut down to size', however the authors found that resentment was a better predictor of participants' responses.

They manipulated resentment by describing the target person as putting forth either a lot of effort or no effort into their academic pursuits. The 'resentment' felt for a lazy high-achiever was a better predictor of negative reactions to the target person and pleasure in the target person's subsequent failure than mere envy. Therefore, it is worth exploring in this study whether it is not merely participants' impressions of gay wealth, nor their own relative socioeconomic status, but also their views on whether gays have 'earned' their wealth in a manner consistent with American values (hard work, 
entrepreneurism, merit, etc) that best predicts their support (or lack thereof) for pro-gay legal reforms.

On the other hand, it may not be sufficient to show a link between low evaluations of gay character and low support for pro-gay legal reform, because that link may be better explained by overall antigay sentiment. Something more specific to the concept of wealth-deservingness should be examined as well. One potential construct for this examination is the Protestant Work Ethic (PWE, also called "Protestant Ethic"), which, at its theoretical inception, was surmised to provide "moral justification for the accumulation of wealth", while simultaneously cautioning against "immoderate consumption and participation in worldly pleasures" (Mirels \& Garrett, 1971, p. 40). Mirels and Garrett found that endorsement of PWE was positively related to the InternalExternal scale, suggesting that people who are high in this construct are generally inclined to "avow responsibility for personally relevant outcomes" (p. 42).

Thus, it can be hypothesized that participants high in PWE will be particularly sensitive to the wealth-deservingness implications of their character judgments regarding gays, and most likely to experience resentment if their perceptions of gay affluence are high and their character judgments tend to be negative. Interestingly, previous research by Malcomnson, Christopher, Franzen, and Keyes (2006) has already discovered a link between scores on the Protestant Work Ethic Scale and negative attitudes toward gays. However, in that study they did not assess beliefs about gay affluence or gays' possession of specific character traits that would make them deserving of wealth, so it cannot be concluded whether the discovered correlation between PWE and heterosexism resulted from resentment, as I hypothesize here, or if it was (as the authors suggest) simply a 
result of the link between PWE and religion, which was in turn highly related to believing that homosexuality is a choice.

\section{Positive Stereotypes as a System Justification Strategy}

It is possible, however, that if a link between perceptions of gay wealth and lower support for gay rights exists, that the mechanism is not emotional (i.e., not a negative reaction to the target which overwhelms underdog support motives), but rather cognitive. It might be that there is something about the belief that gays are wealthy that keeps people from seeing gays as underdogs to begin with.

The 'just world' theory (see Lerner, 2003, summarizing his previous research) suggests that people are motivated to see the world in a way that reinforces their belief that people 'get what they deserve', and that this will have an effect both on behavior (e.g. restorative actions) and cognitions (e.g. blaming the victim). Kay and Jost expand on this concept, weaving just world theory into their system justification framework, and explaining that the same cognitive end "of imbuing the social system with legitimacy" (2003, p. 825) can be achieved either through victim derogation or the alternative route of victim enhancement, wherein 'complementary' stereotypes offset perceptions of a group as disadvantaged (Kay, Jost \& Young, 2005).

In their 2005 examination of the effects of 'benevolent' gender stereotypes on support for the status quo, Jost and Kay explain that "the belief that every group in society possesses some advantages and some disadvantages should increase the sense that the system as a whole is fair, balanced and legitimate" (p. 499). They also suggest in their examination of the effects of the 'poor but honest' stereotype that this system of trading off stereotypes allows members of lower socioeconomic classes to "rationalize 
their own state of relative disadvantage" by imagining themselves "subjectively equal to or even better off than elites" in domains such as happiness and morality (Kay \& Jost, 2003, p. 824).

Thus it is possible that this system-justification strategy could work to excuse people from supporting pro-gay legal reform in two ways: first, by allowing them to imagine that gays aren't so disadvantaged, because at least they have 'something going for them', and second, by permitting the logical inference that gays, being wealthy, must be morally inferior in some way, which may actually make them less deserving of legal protection.

Although his research was not primarily devoted to the topic of systemjustification theory, Walls' (2008a, 2008b, 2009) work is quite illuminating in this regard. Walls was interested in isolating several dimensions of 'modern' heterosexism (aversive, amnestic, paternalistic and positive-stereotypic), and exploring their relationship to one another, and to support for gay rights. From the lens of system-justification logic, the relationship between amnestic and positive-stereotypic heterosexism is of primary interest. Amnestic heterosexism consists of the denial that continued discrimination against gays and lesbians exists. Walls explains:

The amnestic heterosexist suggests that discrimination is a thing of the past, and that lesbians and gay men are treated fairly in contemporary society. The amnestic heterosexist may be making these claims out of ignorance, out of refusal to acknowledge factual information, or even out of life experience where they see many successful lesbians and gay men. (2008b, p. 47). 
Positive-stereotypic heterosexism is another subdomain which Walls examines, but rather than conceiving of positive stereotypes as negatively related to other types of heterosexism and positively related to support for lesbians and gays, Walls (2008a) hypothesized that positive-stereotypic views about gays would function, just like other forms of heterosexism, as a "hierarchy enhancing legitimizing myth". And in fact Walls did find a marginally significant relationship between positive-stereotypic heterosexism and negative attitudes toward gays $(r=.07, p<.10)$.

It is possible that these results can be explained by appealing to system justification theory. That is, it may be the case that the more a participant endorses a 'just world' framework, the more a positive-stereotypic view about a given group may correspond to a view that discrimination against that group is no longer a problem. While belief in a just world was not measured in his study, Walls (2008a) did find a significant correlation between positive-stereotypic heterosexism and amnestic heterosexism $(r=$ $.30, p<.001)$. Returning to the current study, examining the relationship between positive-stereotypic views about gays (including, but not specifically limited to the stereotype that they are affluent) and the belief that discrimination is no longer an issue might lend more support to the system-justification hypothesis.

\section{Pilot Research}

In anticipation of the current study, pilot research was conducted to determine whether or not the stereotype of gays as affluent was salient in the USF student population. A list of 15 demographic groups was compiled, including racial/ethnic, geographical, religious and political categories. Among these groups were listed 'gay men' and 'lesbians'. Participants were asked to rate their perceptions of the wealth of 
each group relative to "the average American" on a 1-9 scale ranging from "Significantly less wealthy than the average American" to "Much more wealthy than the average American". Results showed that participants rated 'gay men' as slightly, but significantly, above the midpoint $(p=.005)$. It is surmised that this difference would only be more pronounced in a non-student population. However, regardless of how common or robust the stereotype may be, the predicted relationship between endorsement of this stereotype and lower levels of support remains of interest.

Interestingly, lesbians were viewed as barely significantly less wealthy than the average American $(p=.041)$. Thus, it is possible that to the extent the stereotype of gays as disproportionately wealthy exists, it is driven by the tendency to (consciously or unconsciously) only consider gay men when considering gays as a category. ${ }^{4}$ The current research will avoid bifurcation of the broader category of homosexuals, because (at least in the realm of legal advocacy) gay men and lesbians must either succeed or fail together. Regardless of any potential advantage in popular support for lesbians as a group distinct from gay men, their legal rights are extremely unlikely to benefit. Thus, in the current project, wherever possible the general term "gays" will be used. It is likely that many participants will (however unconsciously) consider only gay men when making their responses, however this cannot be reliably measured, and will not adversely affect the basic hypotheses or goals of the project.

The pilot study also presented participants with a list of 25 traits or behaviors which were hypothesized to bear (positively or negatively) on perceptions of wealth

\footnotetext{
${ }^{4}$ This is especially ironic considering that lesbians are the ones for whom, debatably, actual evidence of greater affluence exists.
} 
deservingness. Participants were asked to rate each of the items according to how important that item was in their formation of a judgment about whether or not someone had earned his or her wealth. Ratings were made on a -2 to +2 scale, in which a rating of -2 indicated that a trait made the participant "much less likely to think someone had earned his or her wealth" and a rating of +2 indicated the opposite ("much more likely to think someone had earned his or her wealth"). A rating of zero would indicate that the item was not important in the participant's judgment one way or the other. Of the traits included, the ones receiving the highest ratings were hardworking, dedicated, welleducated, entrepreneurial, intelligent, overcame great hardship, high in perseverance, creative, honest and trustworthy. ${ }^{5}$ This was intended to serve as the foundation for a measure of 'wealth-deservingness', to facilitate testing of the resentment hypothesis. Overview of Proposal and Hypotheses

The current study will examine the relationship between perceptions of gay people as relatively affluent and support for pro-gay legal reform. The primary hypothesis (Hypothesis 1) is that higher endorsement of the gay affluence myth will correspond to lower levels of support for pro-gay legal reform. In addition to examining whether a link exists, another key goal of the project is to determine what cognitive or emotional processes moderate or influence this relationship.

The second and third hypotheses relate to the potential impact of envy and resentment on the relationship between perceptions of gay affluence and support for pro-

\footnotetext{
${ }^{5}$ In constructing the final measure, 'Entrepreneurial' and 'Overcame great hardship' were eliminated because they could not be readily translated into a dichotomous dimension (see Methods for more explanation). Trustworthy was eliminated because it was too duplicative of 'honest', and 'high in perseverance' was rephrased 'persevering'.
} 
gay legal reform. Testing for the influence of these two emotions is not quite as straightforward as it first appears. First of all, it is entirely possible that the emotions are experienced unconsciously. That is, while envy and/or resentment may be at the root of the relationship between a given participant's high perception of gay affluence and low degree of support for pro-gay legal reform, he may not be aware of this emotional link in the chain (or indeed that a chain from one to the other exists at all). Second, even if envy and resentment are experienced consciously, participants may be unwilling to admit to these emotional responses, and at the very least it is unlikely that such a measure could be included at a relevant point (i.e., when the emotional response becomes salient) without biasing responses to later portions of the questionnaire.

Therefore, I chose to examine the effect of variables which (in combination) can be logically surmised to produce the target emotions. For instance, an upward comparison between participants' level of affluence and their perceptions of gays' affluence may be expected to produce envy. This is consistent with what Feather and Sherman (2002) discovered. Their study was more conducive to measuring emotional responses directly (because participants were responding to a fictional scenario with a specific target), but as a control variable, they also measured participants' own academic standing. They found a highly significant negative relationship between participants' academic standing and their envy responses.

Thus, in this study, treating participants' economic standing as a moderator of the relationship between perception of gay affluence and support for pro-gay legal reform is an indirect way of testing for the influence of envy. If envy is indeed contributing to the relationship, then I predict (Hypothesis 2) that the strength of the negative relationship 
between perceptions of gay wealth and support for pro-gay reform will be moderated by participants' own perceived affluence (the lower participants' perception of their own affluence, the stronger the relationship).

Next, while Feather and Sherman (2002) were able to both manipulate resentment and measure it directly, neither strategy is ideal in this case. Considering that the goal is to measure effects of resentment on people's every-day, pre-existing perceptions of gays, creating a fictional gay target and manipulating his or her characteristics in such a way as to produce resentment would be counterproductive. Second, for the several reasons described above, directly measuring resentment either toward a fictional gay target with neutral characteristics, or to 'gays' as a group, is an undesirable approach. Thus, as with envy, it is necessary instead to measure variables which, in combination, make it logically permissible to infer resentment on the part of the participant.

Feather and Sherman (2002) found that resentment occurred when a target attained some benefit (high academic achievement) which was not deserved (deservingness was manipulated by varying the levels of effort which the target person was said to have put forth). Using the pilot data collected in anticipation of this project, it will be possible to measure the degree to which participants' believe gays possess the traits or qualities associated with wealth-deservingness, which then in effect can serve as a measure of how deserving of wealth participants believe gays to be. It is possible, however, that this measure of 'wealth deservingness' will be essentially equal to a measure of homophobia, and that its relationship to support for pro-gay legal reform will be a proxy of homophobia's influence. 
One method of addressing this issue is to include another variable to ground the hypothesis more firmly in the realm of wealth deservingness concerns. It is certainly likely that participants will vary in how much importance they place on hard work, dedication, perseverance - in short, the concept of 'earning' what one has. The Protestant Work Ethic Scale (PWE) is one way to measure participants' level of investment in this concept, which may in turn have an effect on their tendency to feel resentment toward gays if they believe that gays possess above-average wealth without possessing the traits that make one deserving of said wealth.

If resentment is contributing to the relationship between perceptions of gay affluence and low support for gays, then I predict (Hypothesis 3) that those participants who are high in PWE and whose ratings on the questionnaire regarding gay character indicate that they do not believe gays possess those positive, wealth-deserving qualities will show the strongest negative relationship between perceptions of gay affluence and support for pro-gay legal reform. Specifically, I predict a three-way interaction between PWE, character beliefs, and perceptions of wealth, influencing support.

Hypotheses 2 (envy) and 3 (resentment) can be thought of as competing alternatives, but they are not mutually exclusive. While it may be the case (as Feather and Sherman discovered) that resentment is a better predictor of low support than envy, it is possible that both constructs contribute equally to the effect, or that individuals differ in how much each construct contributes to their own reactions. Furthermore, the complex and differing methodologies required to test for the influence of these two emotions are not conducive to simultaneous examination, therefore a comparison of their relative strength is not possible under the current proposal. 
Regardless of whether either of these hypotheses is supported - that is, regardless of whether negative affect toward gays is operating in a manner that might undermine an existing underdog-support instinct, it is possible that something about the perception of gays as affluent prevents participants from viewing gays as underdogs to begin with, despite the various tangible ways in which they are treated unequally under the law. Jost and Kay's hypothesis about the role of positive stereotypes in system justification describes why this might occur. Testing for the influence of this construct requires first measuring the degree to which participants experience the system-justification motive, and then applying this construct to the relationship between perceptions of gay wealth and support for gays.

Thus, to say that system justification theory explains the relationship between perceiving gays as affluent and reporting lower levels of support for pro-gay legal reform would mean establishing that the greater a participant's system-justifying tendencies, the more their endorsement of a positive-stereotypic belief about gays (that they are affluent) would predict their tendency to oppose legal changes which would remove existing formal inequalities that disfavor gays. Thus, I predict (Hypothesis 4) that belief in a just world moderates the relationship between perceptions of gay affluence and support for pro-gay legal reform, such that participants who score higher on a just-world scale will show a stronger negative relationship between perceived affluence and support than participants who score lower on the scale.

I also anticipate replicating Walls' finding of a positive correlation between positive-stereotypic and amnestic heterosexism, and predict (Hypothesis 5) that this relationship will be positively moderated by participants' just-world scores. More 
broadly put, I predict that to the extent participants have high system-justification motives, there will be a stronger relationship between holding positive stereotypic views about gays (either believing they are wealthy, or highly endorsing the items measured by Walls' scale) and believing that discrimination against gays is no longer a problem.

It should be noted that while Just World theory and System Justification theory are historically and conceptually distinct, for the limited purposes of this examination, the underlying motivation described by the theories is the same. Thus, a just-world scale was used, because it "provides a reasonably good measure of individual differences in system-justifying tendencies” (Jost \& Hunyady, 2002, p. 117; Jost \& Burgess, 2000).

It is very likely that other variables, such as gender, ethnicity, sexual orientation, political orientation and strength of religious identification, will affect participants' selfreported feelings of support for pro-gay legal reform. Considerable research has already examined the effects of these variables, and they are well outside the scope of this investigation - however, these variables will still be measured so that they will be available for filtering purposes, or for use as potential covariates. Their influence on the data can thus be taken into account and, hopefully, set aside, allowing a more focused examination of the relationships between the variables of interest.

The most significant variable which could be expected to have an effect on support for pro-gay legal reform is, of course, overall levels of heterosexism / homophobia, so a short measure assessing this was also included. Finally, because it is likely that the stereotype of gay affluence is less salient for a college student population (though not entirely absent, as pilot research revealed), data collection was approached from multiple angles in order to expand the participant pool to include non-students. 


\section{Methods}

\section{Participants}

One hundred sixty-one University of South Florida students were recruited through Sona. In order to secure a non-student sample, an additional 175 adult participants were recruited through multiple methods (e.g., by Sona participants for an additional credit; through online social networking tools; through snowball sampling).

Participants who were missing responses for more than $10 \%$ of the questions were eliminated (36 participants total). Two additional participants were eliminated because their responses to the legal support questionnaire appeared to have been compromised by an anchor confusion issue. ${ }^{6}$ Screening for sexual orientation resulted in the deletion of 17 more participants who designated themselves as 4 (bisexual) or higher on the sexual orientation question. The resulting combined sample consisted of 281 participants (119 male; $63.3 \%$ white), 151 of whom reported that they were students.

It became apparent after examining the data that self-report of student status in the non-Sona sample was not entirely reliable. Tracing the IP addresses of computers used to complete the questionnaire revealed that many of the surveys were submitted from within the USF campus. For these participants, only those who indicated that their age was over

\footnotetext{
${ }^{6}$ In the initial construction of the survey, the left and right anchors of the response scale for the legal reform questionnaire were set randomly. It was hoped that this would reduce the impact of response sets, and participants were specifically instructed to pay careful attention to the scales because the left and right anchors might vary randomly. Never the less, during the first week of data collection, it seemed that several participants were confused by this. The two responses that were most obviously compromised were deleted from analyses, and the survey was edited to remove the random anchor setting.
} 
25 were officially designated non-students in subsequent analyses. Also, it appeared after some inquiry that three people who completed the questionnaire at the request of a Sona participant erroneously selected "yes" to the question 'are you a student', simply because they thought they were supposed to. These three were designated non-students in subsequent analyses. Ultimately, this resulted in a sample of 154 (probable) students and 127 (probable) non-students (see Table 1 in Results for full demographics). ${ }^{7}$

\section{Procedure and Materials}

Participants recruited through Sona for the in-lab version of the study were seated in an individual lab room with a computer (the monitor was turned off), and given a consent form describing the procedures of the study and specifically mentioning the additional-credit option for obtaining data from a non-student acquaintance (see Appendix A). After participants gave consent to participate, the researcher turned on the monitor (the questionnaire was already up on the screen), and explained that the participants would be completing the materials online, that there were seven pages of questions, and that once participants had completed and submitted the questionnaire, they should open the door to indicate they were finished. The researcher then left the participant alone, closing the door.

Once participants finished, the researcher prompted once to ask if they would like to take advantage of the additional credit option. If participants declined, they were thanked for their participation and dismissed. If they indicated interest, the researcher orally summarized the instructions (see Appendix A), particularly stressing the

\footnotetext{
${ }^{7}$ According to most sources, the minimum sample size needed to achieve adequate power (.80) to detect moderation with continuous variables is about 200. This goal was achieved in the combined sample, but the non-student sample may be underpowered for some analyses. (See e.g. Champoux \& Peters, 1987).
} 
importance of informed consent, and of not discussing the content of the study until their recruit had completed and submitted the questionnaire. After answering any questions, the researcher assigned participants their random 3-digit identifier using a computerized random number generator, ${ }^{8}$ wrote this number on the instruction sheet and gave this to the participant for reference. These participants were then thanked and dismissed.

Other participants, recruited either via Sona participants, through researcher contacts, or online, were directed to a link. On the first page, participants viewed a consent statement, and were prompted to enter their 3-digit identifier if they were completing the questionnaire on behalf of a Sona participant. These participants then completed the same questionnaire as the Sona participants, except that there was an additional question in the demographics section asking whether or not the participant was a student. After submitting the questionnaire, these participants were directed to a closing screen thanking them for their participation and inviting them to pass the questionnaire on to other people who may be interested, along with a link. Each of the measures included in the questionnaire is described below, and a complete list of items may be found in Appendix B.

Relative / Own Affluence Questionnaires. Participants answered questions measuring their perceptions of the relative socioeconomic status of gays as well as four other demographic groups: 1) African-Americans and Caribbeans; 2) Hispanics; 3) Republicans; and 4) Jews. These four groups were chosen because, in preliminary investigation, they were perceived as having the lowest (1 and 2) and highest ( 3 and 4) levels of affluence. Retaining these groups enables potential comparisons between

\footnotetext{
${ }^{8} \mathrm{http} / /$ random.org/integers/?num $=1 \& \min =100 \& \max =999 \&$ col $=5 \&$ base $=10 \&$ format $=$ html\& $\mathrm{rnd}=$ new
} 
perceptions of gay affluence and affluence of other groups, thus creating a context for interpretation of participants' ratings. Secondly, inclusion of these groups was hoped to reduce the potential for biasing effects that could occur if participants realized too early that the study was concerned principally with attitudes toward gays. This measure was the first of two items measuring participants' perceptions of gay affluence.

The Own Affluence Questionnaire consisted of a single item measure directly following (and made to appear part of) the previous questionnaire. Here participants were directed to rate their own (or their primary household's) wealth on the same scale as above. This served as the first of three items measuring participants' wealth.

Character Beliefs Questionnaire. Next, participants viewed a table (see screen capture in Appendix B), which contained on one axis the same five demographic groups as above, and on the other axis eight dichotomous trait dimensions. The dimensions included were constructed based on data from a pilot investigation. The chosen dimensions reflect those which participants' indicated were most important in influencing their views about whether or not someone had earned his or her wealth.

This particular format was chosen because it would force participants to indicate a spot along each dimension which was either closer to a positive characteristic or to its opposite (there is no 'middle'). At the proposal stage it was suggested that the opposite of traits which make one deserving of wealth might not necessarily be equivalent to traits which make one undeserving of wealth. To address this concern, follow-up pilot tests were conducted to see where the antonyms I had generated fell along the continuum of wealth deservingness. All of these traits were in fact rated as negatively contributing to a 
perception of wealth deservingness, and the ratings for these traits were fairly close complements of their positive counterparts.

One dimension (poor/rich) was added to serve as a backup measure to the relative affluence questionnaire (the second measure of participants' perceptions of gay affluence). As before, participants were prompted in a separate table to rate themselves along these same dimensions. Primarily this was included for consistency, but responses to the poor / rich dimension were used as the second item measuring participant wealth. The seven items measuring participants' beliefs about gays' character traits were averaged $(\alpha=.79)$ to form the Gay Character Composite.

Protestant Work Ethic Scale. Participants then proceeded to the Protestant Work Ethic scale (PWE). This 19-item measure was developed by Mirels and Garrett in 1971, and was used without substantive alteration. The response scale was modified slightly, to be consistent with the remaining predictor scales. The original PWE was on scale ranging from negative three (I disagree strongly) to positive three (I agree strongly) with zero eliminated. In this study, the questionnaire was instead given with a 1 (Strongly Disagree) to 7 (Strongly Agree) scale, with the midpoint (4 - Neither Agree nor Disagree) included. Responses were averaged, reverse-coding where necessary, to form the PWE composite $(\alpha=.74)$.

Just World Beliefs. While the original 20-item measure of Belief in a Just World (JWS) was developed by Rubin and Peplau in 1975, this measure has been criticized a number of times over the years for its low internal reliability and multidimensional structure. Therefore, in the current investigation, a seven-item measure developed by Lipkus (1991) was used instead. Lipkus notes that this seven-item measure (the Global 
Belief in a Just World Scale - GBJWS) is largely unidimensional in structure, and has an internal consistency exceeding that of the original scale. Responses were averaged, reverse coding where necessary, to form a Just World Belief (JWB) composite $(\alpha=.85$ ).

Amnestic and Positive-Stereotypic Heterosexism Subscales. These items are drawn from the Multidimensional Heterosexism Inventory, developed by Walls (2008b). The items selected are those which comprise the subscales of Positive-Stereotypic and Amnestic heterosexism. Walls' Amnestic Heterosexism scale contains four items, two of which are worded to refer to gay men, and two of which are worded to refer to lesbians. In order to increase consistency with the other materials in the study, the wording of these items was changed to refer simply to "gays". Because this change created an appearance of repetitiveness and redundancy, two of the items were then negatively reworded. One item was altered slightly to correct a grammatical error in the original. Responses were averaged, reverse coding where necessary, to form an Amnestic Heterosexism composite $(\alpha=.75)$.

Walls' Positive-Stereotypic scale contains six items, four of which relate to stereotypes about lesbians, and two of which relate to stereotypes about gay men. Because of the stereotypic content, the wording of these items could not believably be changed to simply refer to 'gays', therefore, to restore gender balance, the two items relating to lesbians which Walls' (2008b) original psychometric analyses revealed to have the lowest factor loadings on the "Positive-Stereotypic Heterosexism" construct were eliminated, reducing this scale to four items (two pertaining to lesbians and two pertaining to gay men). Responses were averaged to form a Positive-Stereotypic Heterosexism composite $(\alpha=.74)$. 
Homophobia Scale. These items were drawn from Bouton, Gallaher, Garlinghouse and Leal's 1987 scale, which was chosen primarily for its short length (seven items). The items were presented together with the Amnestic and PositiveStereotypic Heterosexism scales, for a total of fifteen items. The order of the items was set to randomize for each participant. Responses to these seven items were averaged, reverse coding where necessary, to form a General Homophobia composite $(\alpha=.91)$.

Legal Reform Questionnaire. Next, participants answered ten questions measuring their support for various pro-gay legal reforms. I developed the items on this questionnaire to serve as a representative (though not exhaustive) sample of the most topical and central legal inequalities facing gays today. ${ }^{9}$ I further broke down several of the questions to reflect different scales on which an individual may be in favor of reform (state level versus national).

The scale was pilot tested on a sample of 93 students at the University of South Florida (44 male) in order to establish its internal reliability and unidimensionality, and to assure that all items were performing well. Reliability analyses showed that the scale was highly internally consistent $(\alpha=.96)$ and all inter-item correlations were high (ranging from .51 to .99 with an average of .72). Item-total correlations ranged from .66 to .90 with a mean of .83 .

An exploratory factor analysis was performed next, using an oblique rotation (allowing factors to correlate). The results showed one dominant factor accounting for $75 \%$ of the variance. Although the default method of extracting all factors with

\footnotetext{
${ }^{9}$ Happily, while the project was in development, a LGBT-inclusive hate crimes bill was signed into law. Items 9 and 10 of the scale were retained for the current project, but may be eliminated in follow-up studies.
} 
eigenvalues greater than one resulted in extraction of a second factor, a great deal of research in measurement-focused fields has criticized this common practice, recommending instead an approach that takes into consideration the relative significance of factors (see e.g., Lord, 1980). One such method employs visual inspection of the scree plot, retaining only those factors before the point at which the plot levels off (Cattell \& Jaspers, 1967). Another method examines the ratio of the first factor to the next factorif the ratio is greater than 3 , the first factor is prepotent, and the scale is essentially unidimensional (Gorsuch, 1983).

Using either of these methods, the current scale passes the test of unidimensionality. The first extracted factor had an eigenvalue of 7.48, whereas the second extracted factor had an eigenvalue of 1.29 (a ratio of nearly 6 to 1). As a final confirmation, a parallel analysis was performed. ${ }^{10}$ This analysis uses parameters from the pilot data to create a simulated data set, which then allows one to determine the magnitude of eigenvalues that could be extracted merely by chance, with the implication that one should only retain factors with eigenvalues exceeding that which could be extracted by chance (Hayton, Allen \& Scarpello, 2004). For the current scale, only the first factor survived this test. The second factor's eigenvalue (1.29) was below that which the parallel analysis determined could be extracted by chance (1.37), confirming that the scale is essentially unidimensional in structure. Examination of the single factor solution showed that all items were good indicators: loadings ranged from .71 to .92 , with a mean of .86, so all items were retained when proceeding to the full study.

\footnotetext{
${ }^{10}$ The analysis was performed using the program Stata and a script generated by Ender, 2006.
} 
Subsequent to the legal reform scale, participants completed a demographic questionnaire, including items relating to gender, ethnicity, sexual orientation, political orientation, and a four-item measure pertaining to religious affiliation / degree of identification. An additional item regarding household income was included in the demographics section, to serve as the final measure of participant wealth. Presentation of the first two pages of the study (the Relative Affluence and Character Beliefs questionnaires) and the last two pages of the study (Legal Reform and Demographics) were consistent, but the middle three pages (PWE; JWB and the homophobia / heterosexism scales) appeared in random order. 


\section{Results}

The two items measuring participants' impressions of gays' wealth showed acceptable reliability $(\alpha=.71)$. Because the two items were on different scales, their $z-$ transformed values were averaged to form the Gay Wealth Composite. The three items measuring participants' own wealth, similarly, showed adequate reliability $(\alpha=.73)$ and were also averaged using the z-transformed values to create the Own Wealth Composite. After asking whether participants' had a religious preference, and what the denomination was, strength of religious affiliation was measured by two items $(\alpha=.87)$, one asking how strongly the participant identified with his or her chosen denomination, and the second asking about frequency of church attendance. Although numerically these items were on the same scale, the scales were not equivalently worded, so the items were averaged using Z-transformed values to form the Religiosity Composite.

The remaining covariates (sex, race, age, and political identification) were single item measures, and thus did not require reliability analysis, though sex and race required recoding. Sex was dummy coded ( 0 for female, 1 for male), and two different codes were created for race. The ideal contrast would be between those races which previous research has discovered hold significantly higher levels of anti-gay prejudice and those in which no such relationship has been discovered. However, previous research is somewhat contradictory, and at least some evidence has been found for higher antigay attitudes in nearly all of the non-white races included in a standard demographic sheet (see, e.g., Bonilla \& Porter, 1990; Lewis, 2003; Kennedy \& Gorzalka, 2002; Durell, 
Chiong, \& Battle, 2007; Waldner, Sikka, \& Baig, 1999). Thus, one code contrasting white and non-white races was created ( 0 for white, 1 for non-white), and a second code contrasting blacks / African Americans with the other races was created as well (0 for non-black, 1 for black), due to the greater consistency in the literature regarding higher levels of antigay prejudice within that group.

Finally, the ten items measuring support for pro-gay legal reform were once again analyzed for internal reliability and essential unidimensionality. Internal reliability was high $(\alpha=.95)$ and exploratory factor analysis again revealed a dominant first factor, which accounted for approximately $70 \%$ of the variance (first eigenvalue $=6.96$, exceeding the second eigenvalue by a factor of 5). All items loaded satisfactorily onto the dominant factor (loadings ranged from .74 to .91 with an average loading of .83). Responses to these items were then averaged to form the Legal Support Composite.

In order to determine whether the student and non-student sample differed significantly on the variables of interest, t-tests were performed with student status as the grouping variable. There were significant differences in means for the Gay Wealth and Own Wealth Composites, and the Amnestic Heterosexism Composite. Non-students perceived gays as significantly wealthier than did students: $t(279)=-2.93, p=.004$, indicating that the stereotype of gay affluence is more salient among a non-student population. ${ }^{11}$ Non-students' own reported wealth was also significantly higher than that of the students: $t(279)=-2.67, p=.008$. Non-students were also higher in amnestic

\footnotetext{
${ }^{11}$ One-sample t-tests revealed that though the stereotype was more strongly held in the non-student sample, $t(126)=5.829, p<.01$, perceptions of gay wealth were still significantly higher than the midpoint ("the average American") in the combined sample, $t(280)=5.794, p<.01$, and remained significant even when the sample was restricted to students only, $t(153)=2.465, p=.015$.
} 
heterosexism (believing discrimination against gays is no longer an issue): $t(279)=$ $2.836, p=.005$. Finally, the non-student sample was significantly older (mean age difference of 21 years) had significantly fewer males (74 in the student sample, but only 45 in the non-student sample), and significantly fewer ethnic minorities (the student sample was $53.9 \%$ white, whereas the non-student sample was $74.8 \%$ white, see Table 1 below for full demographics). There were no significant differences between students and non-students in any of the other variables of interest.

Table 1. Demographics, by Sample.

\begin{tabular}{|c|c|c|c|}
\hline & Student & Non-Student & Combined \\
\hline \multicolumn{4}{|l|}{ Sex } \\
\hline Male & $74(48.1 \%)$ & $45(35.4 \%)$ & $119(42.3 \%)$ \\
\hline Female & $79(51.3 \%)$ & $82(64.6 \%)$ & $161(57.3 \%)$ \\
\hline \multicolumn{4}{|l|}{ Race } \\
\hline White & $83(53.9 \%)$ & $95(74.8 \%)$ & $178(63.3 \%)$ \\
\hline Black & $34(22.1 \%)$ & $9(7.1 \%)$ & $43(15.3 \%)$ \\
\hline Hispanic & $21(13.6 \%)$ & $10(7.9 \%)$ & $31(11 \%)$ \\
\hline Asian & $7(4.5 \%)$ & $5(3.9 \%)$ & $12(4.3 \%)$ \\
\hline Indian & $1(.6 \%)$ & $1(.8 \%)$ & $2(.7 \%)$ \\
\hline Arab & $1(.6 \%)$ & 0 & $1(.4 \%)$ \\
\hline Other & $7(4.5 \%)$ & $6(4.7 \%)$ & $13(4.6 \%)$ \\
\hline Age & $20.50(2.6)$ & $41.55(12.7)$ & $29.85(13.6)$ \\
\hline Political Orientation & $3.64(1.6)$ & $3.79(1.7)$ & $3.71(1.7)$ \\
\hline \multicolumn{4}{|l|}{ Religiosity } \\
\hline $\begin{array}{r}\text { Strength of } \\
\text { Identification }\end{array}$ & $2.40(1.9)$ & $2.33(2.1)$ & 2.37 (1.9) \\
\hline Church Attendance & $2.06(1.6)$ & $2.05(1.8)$ & $2.06(1.7)$ \\
\hline Income & $6.11(4.1)$ & $7.47(4.3)$ & $6.72(4.2)$ \\
\hline
\end{tabular}

Note: One participant failed to complete any demographic questions. Sex and Race are given as frequencies with percentages in parentheses; the rest of the variables are given as means, with standard deviations in parentheses. See demographics page in Appendix B for original scales. 
Because the student and non-student sample differed significantly on the primary predictor, as well as on two secondary predictors and two potential covariates, all analyses were performed on both the combined sample and on a restricted, non-studentonly sample. The results presented below, however, pertain to the combined sample, unless otherwise noted.

First, in order to determine which covariates should be included in subsequent tests, a regression analysis was performed regressing the Legal Support Composite on Homophobia, Sex, Race, Age, Religiosity, and Political Identification. The two covariates which emerged as significant (negative) predictors of support were homophobia and religiosity. Race was only a significant predictor when recoded to contrast participants who identified as black with participants of all other racial / ethnic identifications, however the direction of the influence was the opposite of what would have been indicated by the literature. Thus, to maximize simplicity, only homophobia and religiosity were included as covariates and were entered in the first step of the subsequent regression analyses. ${ }^{12}$

To test the primary hypothesis, that the perception of gays as affluent would negatively predict support for pro-gay legal reform, a hierarchical regression analysis was performed, using the procedures outlined by Aiken and West (1991), regressing Legal Support on Gay Wealth, with Homophobia and Religiosity entered on the first step. Gay Wealth significantly negatively predicted Support $(\beta=-.071, t(270)=-2.06, p=.041)$ and resulted in a slight, but significant $\Delta R^{2}$ (see Table 2A).

\footnotetext{
${ }^{12}$ Correlation tables depicting the bivariate relationships among all variables of interest can be found at the end of the results section.
} 
Table 2A. Regressing Support on Perceptions of Gay Wealth (Combined Sample).

\begin{tabular}{|r|c|c|c|c|c|}
\hline & $\mathrm{B}$ & $\mathrm{SE}(\mathrm{B})$ & $\beta$ & $\mathrm{R}^{2}$ & $\Delta \mathrm{R}^{2}$ \\
\hline Step 1 & & & & .682 & \\
\hline Intercept & 5.14 & .06 & & & \\
\hline Homophobia & -.87 & .04 & $-.79^{* * *}$ & & \\
\hline Step 2 & -.14 & .07 & $-.08^{*}$ & & \\
\hline Religiosity & & & & .687 & .005 \\
\hline Intercept & 5.14 & .06 & & & \\
\hline Homophobia & -.89 & .04 & $-.80^{* * *}$ & & \\
\hline Religiosity & -.13 & .07 & $-.07^{\dagger}$ & & \\
\hline Gay Wealth & -.14 & .07 & $-.07^{*}$ & & \\
\hline
\end{tabular}

Note: Asterisks denote significant predictors: $p<.05^{*}, p<.01^{* *}, p<.001^{* * *}$; marginally significant predictors are also noted: $p<.1^{\dagger}$.

In the non-student sample, the relationship was even stronger $(\beta=-.143, t(120)=-2.74, p$ $=.007 ; \Delta R^{2}=.02$, see Table $2 \mathrm{~B}$ and Figure 1$)$. Thus, the primary hypothesis was supported.

Table 2B. Regressing Support on Perceptions of Gay Wealth (Non-Student Sample).

\begin{tabular}{|r|c|c|c|c|c|}
\hline & $\mathrm{B}$ & $\mathrm{SE}(\mathrm{B})$ & $\beta$ & $\mathrm{R}^{2}$ & $\Delta \mathrm{R}^{2}$ \\
\hline Step 1 & & & & .660 & \\
\hline Intercept & 5.25 & .09 & & & \\
\hline Homophobia & -.89 & .07 & $-.74^{* * *}$ & & \\
\hline Step 2 & & .11 & $-.16^{* *}$ & & \\
\hline Religiosity & -.31 & & & .680 & .020 \\
\hline Intercept & 5.25 & .09 & & & \\
\hline Homophobia & -.91 & .07 & $-.76^{* * *}$ & & \\
\hline Religiosity & -.29 & .11 & $-.15^{* *}$ & & \\
\hline Gay Wealth & -.29 & .10 & $-.14^{* *}$ & & \\
\hline
\end{tabular}

Note: Asterisks denote significant predictors: $p<.05^{*}, p<.01^{* *}, p<.001^{* * *}$. 


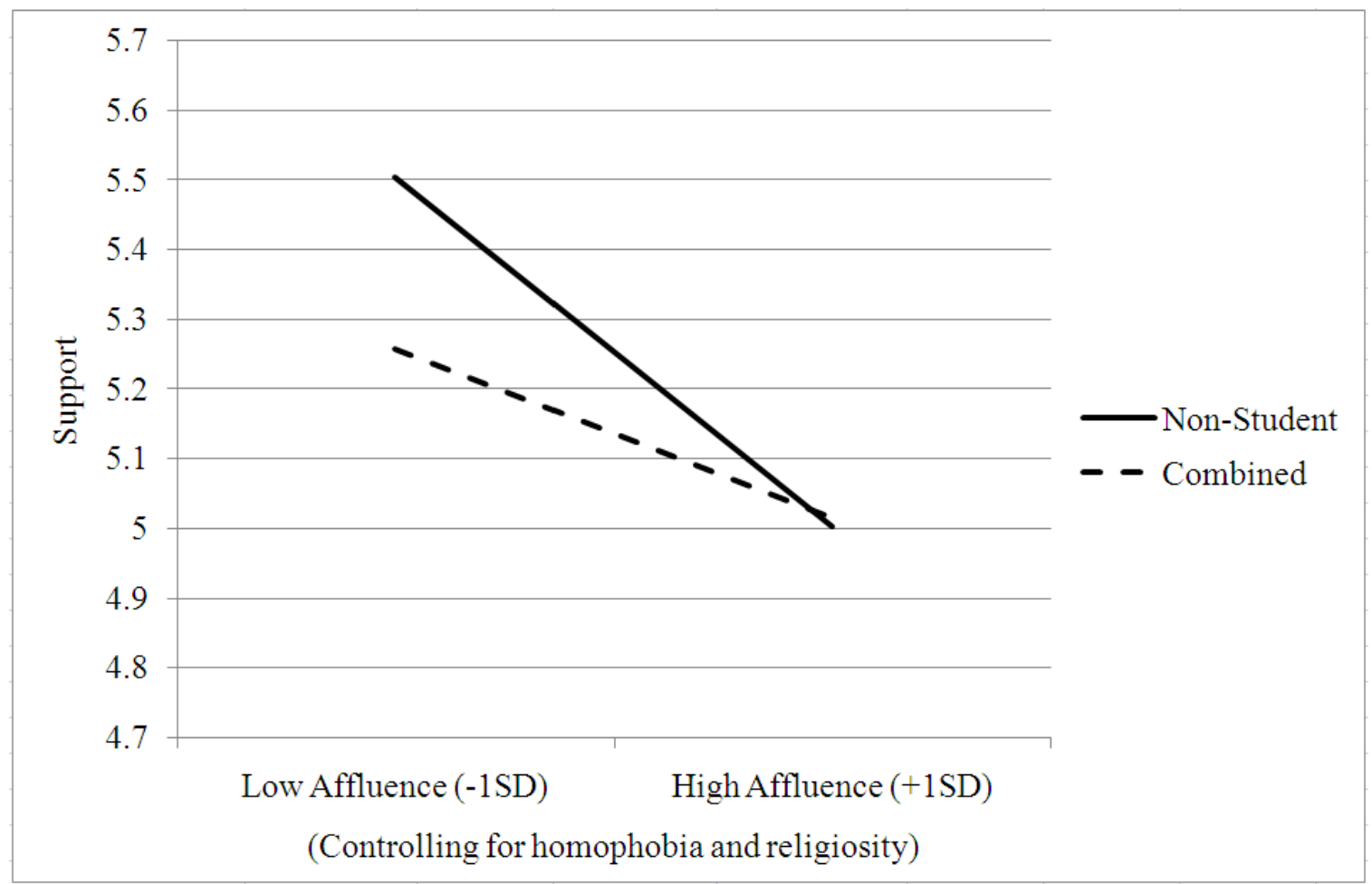

Figure 1. Support as a function of affluence perceptions, separated by sample.

Because the subsequent hypotheses involved interactions between perceptions of gays' wealth and other variables, the predictors were first centered in order to reduce the effects of collinearity. Own Wealth and Gay Character were reverse coded so that higher values would indicate less wealth and more negative character views of gays (respectively). This was done to facilitate consistency and thereby aid interpretability of the results, so that the predicted relationship of each of the predictors to the dependent variable would be negative. Next, interaction terms were computed for 'Gay Wealth X Own Wealth', 'Gay Wealth X Gay Character', 'Gay Wealth X PWE', 'Gay Character X PWE', 'Gay Wealth X Gay Char X PWE', and 'Gay Wealth X JWB'. In the subsequent analyses, unless otherwise noted, centered versions of homophobia and religiosity were entered on the first step, and the centered versions of the first order predictors were used. 
The second hypothesis predicted that the relationship between perceptions of gay affluence and support for pro-gay legal reform would be moderated by participants' envy of a wealthier target (as measured by the perception that gay people are wealthier than oneself). To test this, Support was regressed on Gay Wealth, Own Wealth and their interaction. The results did not support the hypothesis. Participants' own wealth was a significant predictor of support $(\beta=.079, t(270)=2.29, p=.023)$, but in the opposite direction from what was theorized. That is, the less wealthy the participant, the more supportive he or she was of pro-gay legal reform (see Table 3 below). The effect of the interaction term was in the same direction, but did not significantly predict support $(\beta=$ $.055, t(270)=1.61, p=.109)$.

Table 3. Regressing Support on Perceptions of Gay Wealth and Participants' Own Wealth (Combined Sample).

\begin{tabular}{|r|c|c|c|c|c|}
\hline & $B$ & $S E(B)$ & $\beta$ & $R^{2}$ & $\Delta R^{2}$ \\
\hline Step 1 & & & & .682 & \\
\hline Intercept & 5.14 & .06 & & & \\
\hline Homophobia & -.87 & .04 & $-.79^{* * *}$ & & \\
\hline Step 2 & -.14 & .07 & $-.08^{*}$ & & \\
\hline Religiosity & & & & .696 & .014 \\
\hline Intercept & 5.16 & .06 & & & \\
\hline Homophobia & -.90 & .04 & $-.81^{* * *}$ & & \\
\hline Religiosity & -.11 & .07 & -.06 & & \\
\hline Gay Wealth & -.12 & .07 & $-.06^{\dagger}$ & & \\
\hline Own Wealth & .16 & .07 & $.08^{*}$ & & \\
\hline Gay X Own Wealth & .13 & .08 & .06 & & \\
\hline
\end{tabular}

Note: Asterisks denote significant predictors: $p<.05^{*}, p<.01 * *, p<.001^{* * *}$; marginally significant predictors are also noted: $p<.1^{\dagger}$.

Interestingly, this unexpected result only emerged in the combined sample. For the non-student sample, in which both perceptions of gay wealth and participants' own 
wealth were significantly higher, participants' own wealth did not significantly predict support $(\beta=.041, t(118)=0.77, p=.441){ }^{13}$ To reduce the concern that the result might be an artifact of the wealth gap between students and non-students, I re-tested the hypothesis using a "wealth difference" variable instead of participants' own wealth. ${ }^{14}$ This variable was created by subtracting participants' own wealth from their perceptions of gay wealth, and this variable was centered. Thus, positive values represent a perception that gays are wealthier than the participant, and negative values represent a perception that gays are less wealthy than the participant.

In a regression model which included only homophobia, religiosity and this new variable, wealth difference did not significantly predict support, either in the combined or non-student sample. However, when gay wealth was included in the model, as well as the interaction between gay wealth and the wealth difference, the result observed above was replicated (see Table 4 below). That is, while perceptions of gays as wealthy negatively predicted support $(\beta=-.140, t(270)=-3.10, p=.002)$, the wealth difference positively predicted support $(\beta=.107, t(270)=2.38, p=.018)$. Again, this emerged only in the combined sample - the relationship between wealth difference and support in the non-student sample was in the same direction, but was not significant $(\beta=.038, t(118)=$ $0.57, p=.567)$. In neither sample was the interaction term significant.

\footnotetext{
${ }^{13}$ The interaction term might be considered marginally significant: $\beta=.088, t(118)=1.68, p=.096$.

${ }^{14}$ If non-students were higher in both, I surmised that using a difference variable would wash this difference out. In fact this was the case. Whereas non-students were significantly higher than students both in perceptions of gay wealth and in their own wealth, a t-test revealed no significant difference between students and non-students in the wealth difference variable, $t(279)=-.203, p=.84$.
} 
Table 4. Re-analysis: Using Wealth Difference Variable in Place of Participant Wealth (Combined Sample).

\begin{tabular}{|r|c|c|c|c|c|}
\hline & $\mathrm{B}$ & $\mathrm{SE}(\mathrm{B})$ & $\beta$ & $\mathrm{R}^{2}$ & $\Delta \mathrm{R}^{2}$ \\
\hline Step 1 & & & & .682 & \\
\hline Intercept & 5.14 & .06 & & & \\
\hline Homophobia & -.87 & .04 & $-.79^{* * *}$ & & \\
\hline Religiosity & -.14 & .07 & $-.08^{*}$ & & \\
\hline & & & & .693 & .011 \\
\hline Step 2 & 5.14 & .06 & & & \\
\hline Homophobia & -.89 & .04 & $-.81^{* * *}$ & & \\
\hline Religiosity & -.11 & .07 & -.06 & & \\
\hline Gay Wealth & -.27 & .09 & $-.14^{* *}$ & & \\
\hline Wealth Difference & .16 & .07 & $.11^{*}$ & & \\
\hline Gay X Wealth Diff & -.01 & .04 & -.01 & & \\
\hline
\end{tabular}

Note: Asterisks denote significant predictors: $p<.05^{*}, p<.01^{* *}, p<.001^{* * *}$.

The third hypothesis proposed that perceptions of gay affluence might negatively predict support if participants were resentful because they did not believe gays possess the character traits that make one deserving of wealth. To test this, Support was regressed on Gay Wealth, Gay Character, and PWE, in addition to their interaction terms. Aside from Gay Wealth, none of the variables significantly predicted support. However, the original rationale for including PWE as a predictor to test this hypothesis was that character beliefs about gays might be merely a reflection of overall homophobia, and thereby influence support for reasons not bearing on the specific hypothesis under investigation.

That is, the link between participants' negative character beliefs and lower support might have been merely a reflection of their general antipathy, rather than resentment. Including PWE in the model was hoped to reduce this risk, because of that construct's link to the concept of wealth-deservingness. Also, previous research had 
found PWE and homophobia to be positively correlated, and that finding was replicated here $(r=.175, p<.01){ }^{15}$ Inclusion of homophobia as a covariate entered on the first step obviated the need to include PWE. Because the variance in the dependent variable that was attributable to homophobia had already been accounted for, any additional predictive contribution by negative character beliefs about gays would not simply be a reflection of those aversive attitudes.

Therefore, a second regression was performed, eliminating PWE as a predictor, and the interaction terms of which it was a part. While this did not substantially influence the results in the combined sample, in the non-student sample a significant interaction emerged between Gay Wealth and Gay Character $(\beta=-.111, t(118)=-2.13, p$ $=.035$, see Table 5 below, and Figure 2), such that both perceptions of gay wealth, and the interaction of wealth and negative character perceptions independently predicted lower support, even after accounting for homophobia.

Table 5. Regressing Support on Perceptions of Gay Wealth and Character Beliefs (NonStudent Sample).

\begin{tabular}{|r|c|c|c|c|c|}
\hline & $\mathrm{B}$ & $\mathrm{SE}(\mathrm{B})$ & $\beta$ & $\mathrm{R}^{2}$ & $\Delta \mathrm{R}^{2}$ \\
\hline Step 1 & & & & .660 & \\
\hline Intercept & 5.25 & .09 & & & \\
\hline Homophobia & -.89 & .07 & $-.74^{* * *}$ & & \\
\hline Religiosity & -.31 & .11 & $-.16^{* *}$ & & \\
\hline & & & & .692 & .032 \\
\hline Intercept & 5.22 & .09 & & & \\
\hline Homophobia & -.93 & .07 & $-.77^{* * *}$ & & \\
\hline Religiosity & -.30 & .11 & $-.16^{* *}$ & & \\
\hline Gay Wealth & -.30 & .11 & $-.15^{* *}$ & & \\
\hline Gay Character & .02 & .10 & .01 & & \\
\hline Gay Wealth X Char & -.17 & .08 & $-.11^{*}$ & & \\
\hline
\end{tabular}

Note: Asterisks denote significant predictors: $p<.05^{*}, p<.01^{* *}, p<.001^{* * *}$.

\footnotetext{
${ }^{15}$ The relationship was even stronger in the non-student sample, $r=.33, p<.001$.
} 


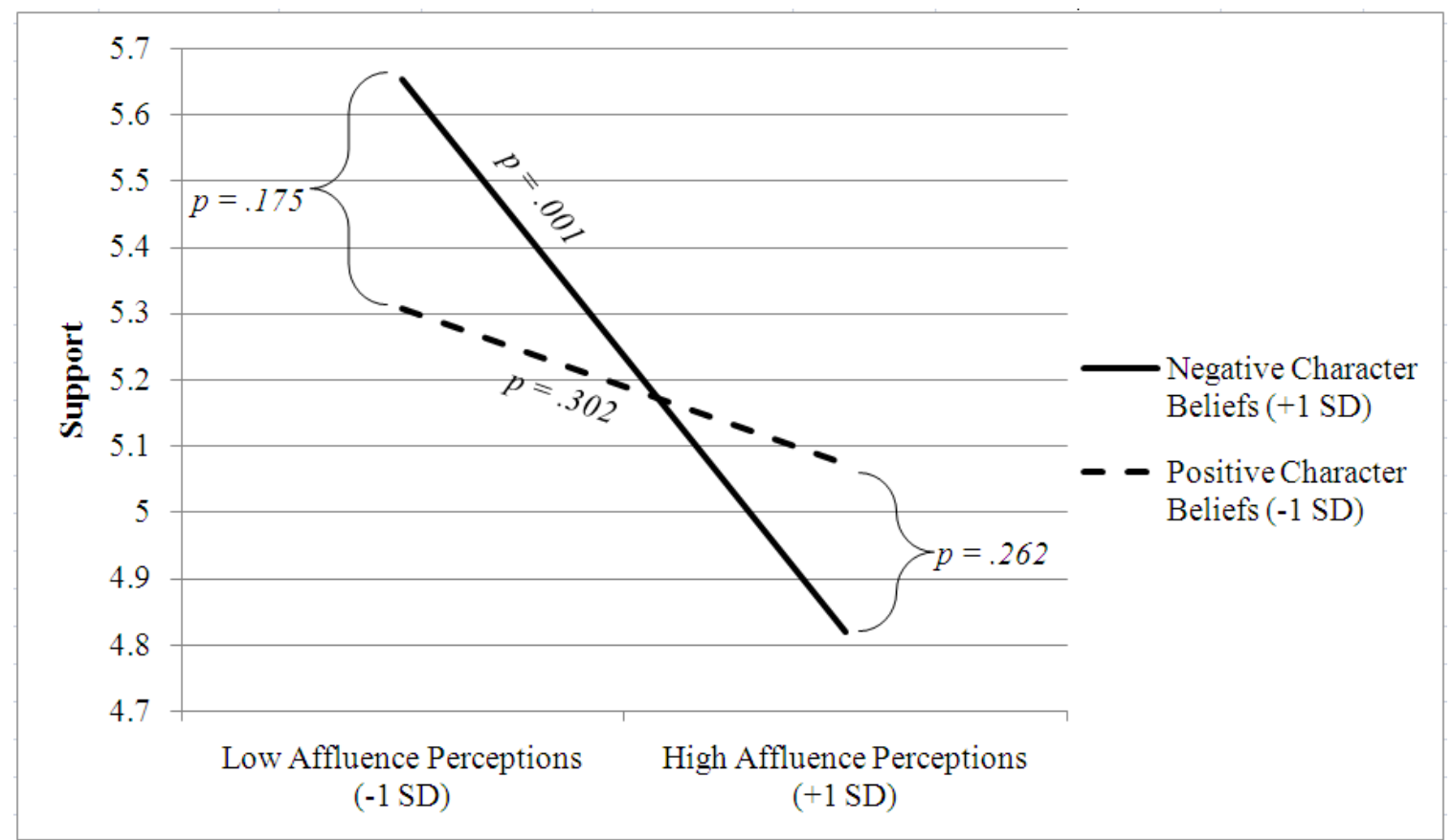

Figure 2. Support as a function of affluence and character perceptions (non-student sample).

To further clarify this result, I divided the non-student sample into three groups based on their scores on the gay character composite. The negative relationship between perceptions of gay wealth and support (controlling for homophobia and religiosity) was not significant either for the group with the most positive character beliefs about gays ( $r$ $=-.113, p=.453)$ or for the group with moderate character beliefs $(r=-.310, p=.079)$, but was significant for the group with the most negative character beliefs $(r=-.332, p=$ .039). Interestingly, although in the regression analysis described above, the interaction between gay wealth and gay character was not a significant predictor of support for the combined sample, the same pattern of results was found when I conducted this threegroup analysis on that sample: group 1 (positive character beliefs), $r=-.071, p=.492$; group 2 (moderate character beliefs), $r=-.140, p=.221$; group 3 (negative character beliefs), $r=-.239, p=.020$. 
Next, the system justification hypothesis was tested, by regressing Support on Gay Wealth, the JWB Composite, and their interaction. In addition to gay wealth perceptions, belief in a just world also significantly negatively predicted support $(\beta=$ $.073, t(270)=-2.14, p=.034)$. The interaction between the two, however, was not significant (see Table 6A, below, and Figure 3).

Table 6A. Regressing Support on Perceptions of Gay Wealth and Just World Beliefs (Combined Sample).

\begin{tabular}{|r|c|c|c|c|c|}
\hline \multicolumn{1}{|c|}{} & $\mathrm{B}$ & $\mathrm{SE}(\mathrm{B})$ & $\beta$ & $\mathrm{R}^{2}$ & $\Delta \mathrm{R}^{2}$ \\
\hline Step 1 & & & & .682 & \\
\hline Homophobia & -.87 & .04 & $-.79^{* * *}$ & & \\
\hline Religiosity & -.14 & .07 & $-.08^{*}$ & & \\
\hline Step 2 & & & & .693 & .011 \\
\hline Intercept & 5.13 & .06 & & & \\
\hline Homophobia & -.88 & .04 & $-.79^{* * *}$ & & \\
\hline Religiosity & -.15 & .07 & $-.08^{*}$ & & \\
\hline Gay Wealth & -.14 & .07 & $-.07^{*}$ & & \\
\hline Just World Belief & -.11 & .05 & $-.07^{*}$ & & \\
\hline Gay Wealth X JWB & -.06 & .06 & -.03 & & \\
\hline
\end{tabular}

Note: Asterisks denote significant predictors: $p<.05^{*}, p<.01^{* *}, p<.001^{* * *}$. 


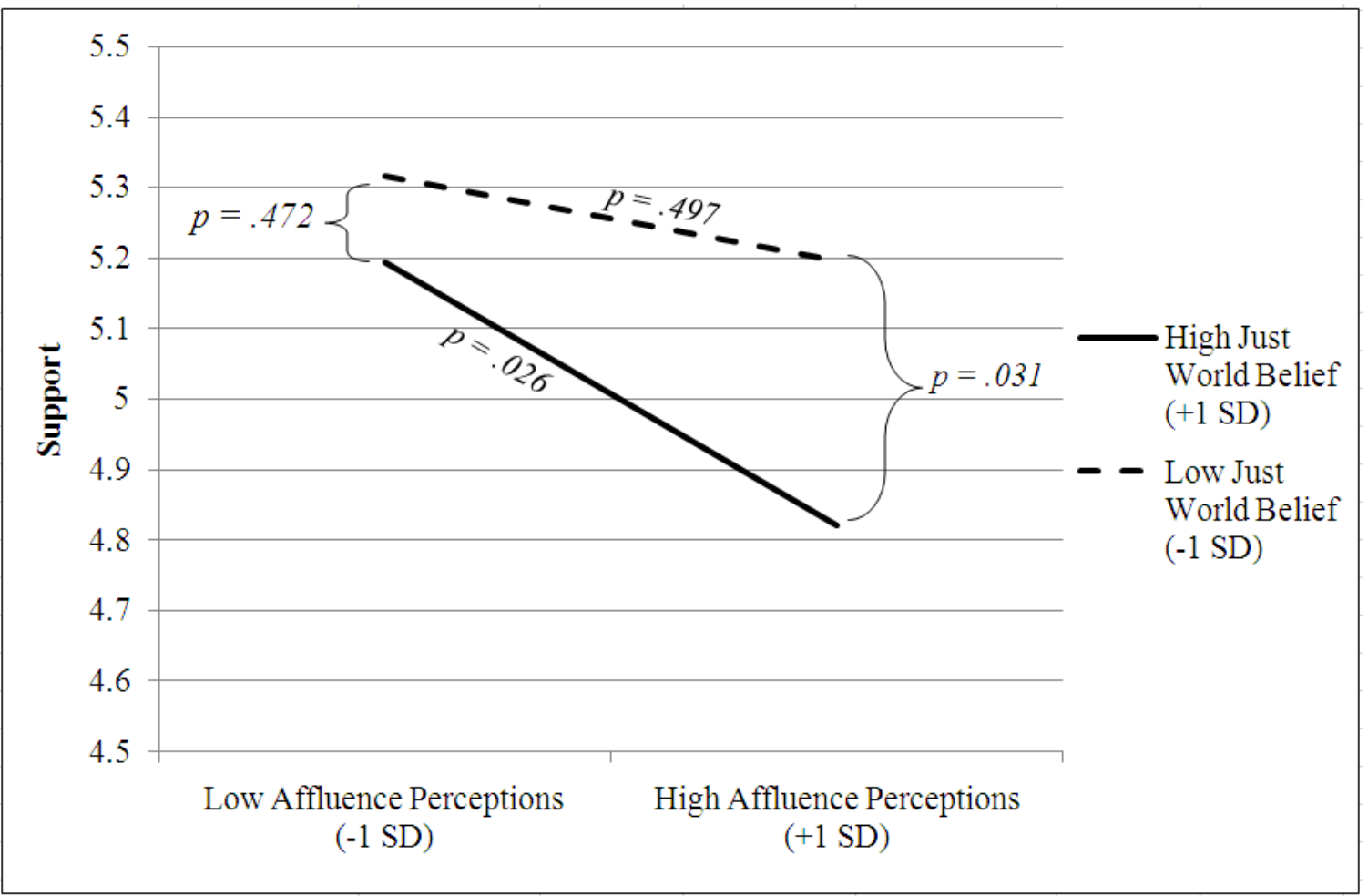

Figure 3. Support as a function of affluence perceptions and just world belief (combined sample).

Interestingly, when positive-stereotypic heterosexism was added into the model (along with the attendant interaction terms), there emerged a significant three-way interaction between perceptions of gay wealth, just world belief and positive stereotypic heterosexism, negatively predicting support $(\beta=-.074, t(266)=-2.05, p=.042$, see Table $6 \mathrm{~B}){ }^{16}$

\footnotetext{
${ }^{16}$ For both of the foregoing analyses, the trend in the non-student sample was similar, but the results were non-significant.
} 
Table 6B. Re-analysis, Adding Positive Stereotypic Heterosexism to the Model (Combined Sample).

\begin{tabular}{|r|c|c|c|c|c|}
\hline & $\mathrm{B}$ & $\mathrm{SE}(\mathrm{B})$ & $\beta$ & $\mathrm{R}^{2}$ & $\Delta \mathrm{R}^{2}$ \\
\hline Step 1 & & & & .682 & \\
\hline Intercept & 5.14 & .06 & & & \\
\hline Homophobia & -.87 & .04 & $-.79^{* * *}$ & & \\
\hline Religiosity & -.14 & .07 & $-.08^{*}$ & & \\
\hline & & & & .701 & .019 \\
\hline Intercept & 5.13 & .06 & & & \\
\hline Homophobia & -.88 & .04 & $-.80^{* * *}$ & & \\
\hline Religiosity & -.14 & .07 & $-.08^{*}$ & & \\
\hline Gay Wealth & -.13 & .07 & $-.07^{\dagger}$ & & \\
\hline Positive-Stereotypes & -.001 & .05 & $-.07^{\dagger}$ & & \\
\hline Gay Wealth X JWB & -.07 & .05 & .000 & & \\
\hline Gay Wealth X PosSter & .10 & .06 & -.04 & & \\
\hline JWB X PosSter & .02 & .04 & .07 & & \\
\hline Wealth X JWB X PosSter & -.11 & .05 & $-.07^{\dagger}$ & & \\
\hline
\end{tabular}

Note: Asterisks denote significant predictors: $p<.05^{*}, p<.01^{* *}, p<.001^{* * *}$; marginally significant predictors are also noted: $p<.1^{\dagger}$.

I had also predicted that participants' amnestic and positive-stereotypic heterosexism ratings would be positively correlated. In fact, there was no correlation, either at the bivariate level, or when controlling for overall homophobia and religiosity. Interestingly, however, both variables were significantly positively correlated with just world belief. When, as planned, I regressed amnestic heterosexism on positive heterosexism, JWB, and their interaction, I found that while belief in a just world significantly predicted amnestic heterosexism $(\beta=.134, t(270)=2.38, p=.018)$, positive-stereotypic heterosexism and their interaction did not.

I had anticipated that the effect of JWB on the relationship between amnestic and positive stereotypic heterosexism might not be linear. That is, I left open the possibility 
that rather than JWB affecting their correlation in a steady progression, that the predicted positive relationship between amnestic and positive-stereotypic heterosexism might only emerge for those participants who were especially high in JWB. To test this possibility, I created a variable which categorized participants whose JWB ratings were one standard deviation above the mean as 'high believers' $(N=43)$. While this isolation still failed to uncover the predicted relationship between amnestic and positive stereotypic heterosexism (no significant correlation for 'high believers' either), one interesting finding did emerge.

While perceptions of gay wealth and amnestic heterosexism were uncorrelated for the low-medium just world believers $(N=233)$, there was a significant partial correlation between perceptions of gay wealth and amnestic heterosexism for high believers, after controlling for overall homophobia and religiosity $(r=.332, p=.034)$. That is, for those participants high in just world belief, the perception of gays as affluent was significantly positively related to the belief that discrimination against gays is no longer a problem. ${ }^{17}$ Perceptions of gay wealth were also significantly correlated with positive stereotypic heterosexism for high believers $(r=.355, p=.020)$ but not for low-medium believers $(r=$ $.046, p=.485)$. Finally, the correlation between perceptions of gay wealth and more positive character beliefs about gays was marginally significantly stronger for high believers $(r=-.520)$ than low-medium believers $(r=-.317): z=1.45, p=.07$.

\footnotetext{
${ }^{17}$ This correlation was even higher in the non-student sample $(r=.387)$, but the relationship did not quite reach significance $(p=.083)$, most likely due to the even more restricted sample size $(N=23)$.
} 
Table 7A. Bivariate Correlations Among Variables of Interest in Combined Sample

\begin{tabular}{|c|c|c|c|c|c|c|c|c|c|c|c|c|c|}
\hline & 1. & 2. & 3. & 4. & 5. & 6. & 7. & 8. & 9. & 10. & 11. & 12. & 13. \\
\hline \multicolumn{14}{|l|}{ Primary Variables } \\
\hline 1. Support & & & & & & & & & & & & & \\
\hline 2. Gay Wealth & .05 & & & & & & & & & & & & \\
\hline 3. Own Wealth & .08 & $-.16^{* *}$ & & & & & & & & & & & \\
\hline 4. Gay Character & $-.31 * *$ & $-.35 * *$ & .03 & & & & & & & & & & \\
\hline 5. PWE & $-.21 * *$ & .09 & -.01 & $-.11^{\dagger}$ & & & & & & & & & \\
\hline 6. JWB & $-.14 *$ & -.07 & -.03 & -.01 & $.47 * *$ & & & & & & & & \\
\hline 7. Amnestic & $-.42 * *$ & .01 & .04 & $.21 * *$ & .08 & $.16^{* *}$ & & & & & & & \\
\hline 8. Pos. Stereotypic & -.02 & .09 & -.01 & -.04 & $.21 * *$ & $.14^{*}$ & -.02 & & & & & & \\
\hline \multicolumn{14}{|l|}{ Covariates } \\
\hline 9. Homophobia & $-.82 * *$ & $-.15^{*}$ & .04 & $.37 * *$ & $.18^{* *}$ & $.10^{\dagger}$ & $.39 * *$ & .01 & & & & & \\
\hline 10. Religiosity & $-.42 * *$ & .00 & $-.12^{\dagger}$ & .06 & $.23^{* *}$ & -.02 & $.18^{* *}$ & $-.11^{\dagger}$ & $.43^{* *}$ & & & & \\
\hline 11. Sex & -.08 & -.02 & .06 & .07 & -.04 & .04 & -.00 & .05 & .04 & $-.18 * *$ & & & \\
\hline 12. Race & -.10 & $-.18 * *$ & $.15^{*}$ & $.12^{\dagger}$ & .04 & -.07 & -.01 & -.04 & $.23 * *$ & $.13 *$ & -.06 & & \\
\hline 13. Political & $-.36 * *$ & .02 & $-.14 *$ & .05 & $.27 * *$ & $.18^{* *}$ & $.25^{* *}$ & $-.12 *$ & $.35^{* *}$ & $.26^{* *}$ & .02 & $-.16^{* *}$ & \\
\hline 14. Age & -.02 & $.14^{*}$ & $-.15 *$ & $-.12 *$ & -.05 & $-.11^{\dagger}$ & $.18^{* *}$ & .04 & .06 & .10 & $-.16^{* *}$ & $-.16 * *$ & .09 \\
\hline
\end{tabular}

Note: Own Wealth and Gay Character are reverse coded, so that higher values correspond to lower wealth and more negative views, respectively. Gender is coded 1 for male, 0 for female; race is coded 1 for black, 0 for non-black. Higher political orientation values indicate greater conservatism. Significance of correlations is indicated by asterisks: $p<.05^{*} ; p<.01^{* *} ; \mathrm{p}<.10^{\dagger}$. 
Table 7B. Bivariate Correlations Among Variables of Interest in Non-Student Sample

\begin{tabular}{|c|c|c|c|c|c|c|c|c|c|c|c|c|c|}
\hline & 1. & 2. & 3. & 4. & 5. & 6. & 7. & 8. & 9. & 10. & 11. & 12. & 13. \\
\hline \multicolumn{14}{|l|}{ Primary Variables } \\
\hline 1. Support & & & & & & & & & & & & & \\
\hline 2. Gay Wealth & -.05 & & & & & & & & & & & & \\
\hline 3. Own Wealth & .07 & $-.25 * *$ & & & & & & & & & & & \\
\hline 4. Gay Character & $-.17^{\dagger}$ & $-.27 * *$ & .03 & & & & & & & & & & \\
\hline 5. PWE & $-.30 * *$ & .06 & .02 & -.08 & & & & & & & & & \\
\hline 6. JWB & $-.20 *$ & -.11 & .05 & .03 & $.51 * *$ & & & & & & & & \\
\hline 7. Amnestic & $-.54 * *$ & .01 & .05 & $.17^{\dagger}$ & $.19 *$ & $.22 * *$ & & & & & & & \\
\hline 8. Pos. Stereotypic & -.02 & $.16^{\dagger}$ & .03 & .02 & $.26^{* *}$ & $.20^{*}$ & -.08 & & & & & & \\
\hline \multicolumn{14}{|l|}{ Covariates } \\
\hline 9. Homophobia & $-.79 * *$ & -.12 & .06 & $.25 * *$ & $.33 * *$ & $.24 * *$ & $.55^{* *}$ & .06 & & & & & \\
\hline 10. Religiosity & $-.45 * *$ & .02 & -.11 & .06 & $.18^{*}$ & -.06 & $.25^{* *}$ & $-.21 *$ & $.39 * *$ & & & & \\
\hline 11. Sex & -.02 & .05 & .09 & -.04 & -.05 & .04 & -.08 & .05 & -.02 & $-.19 *$ & & & \\
\hline 12. Race & .06 & -.13 & .05 & .02 & .04 & .04 & .06 & .07 & .09 & -.02 & $-.21^{*}$ & & \\
\hline 13. Political & $-.44 * *$ & -.00 & $-.16^{\dagger}$ & .04 & $.30 * *$ & $.23^{* *}$ & $.29 * *$ & -.07 & $.47 * *$ & $.30 * *$ & .05 & -.10 & \\
\hline 14. Age & $-.19 *$ & -.00 & -.12 & $-.18^{*}$ & .11 & -.05 & .09 & -.02 & $.28^{* *}$ & $.25^{* *}$ & $-.17^{\dagger}$ & .00 & .13 \\
\hline
\end{tabular}

Note: Own Wealth and Gay Character are reverse coded, so that higher values correspond to lower wealth and more negative views, respectively. Gender is coded 1 for male, 0 for female; race is coded 1 for black, 0 for non-black. Higher political orientation values indicate greater conservatism. Significance of correlations is indicated by asterisks: $p<.05^{*} ; p<.01^{* *} ; \mathrm{p}<.10^{\dagger}$. 


\section{Discussion}

The driving question behind the current investigation was whether perceiving gays as wealthy would lead to lower levels of support for pro-gay legal reform. This suspicion was confirmed. After controlling for general homophobia and strength of religious identification (both of which were very strongly associated with lower levels of support), viewing gays as wealthier corresponded with reduced support for gays' legal rights. This relationship was particularly strong in the non-student sample, for which the stereotype of gay affluence seemed to be more salient.

While it is easily observed by examining the regression tables that the bulk of the variance in support was predicted by homophobia, and to a lesser extent religiosity, the current findings remain practically significant given the current state of public opinion regarding gay rights issues in this country. On many matters, polls suggest that the country is roughly evenly divided, and that results can vary widely based simply on the way in which the questions are phrased. Given these circumstances, any additional information that can help to sway public opinion in favor of equality is important, and might on occasion make the difference between success and failure.

In addition to establishing the relationship between affluence perceptions and support, I was also interested in what mechanisms might underlie this relationship. I investigated envy, resentment, and system justification tendencies as three potential (though not mutually exclusive) alternatives. The envy hypothesis was not supported, as the interaction between perceiving gays as wealthy and the self as not wealthy was not 
significantly related to levels of support. In fact, after controlling for the influence of other variables, participants with lower incomes actually tended to be more supportive than those with higher incomes - an anomaly which is discussed in somewhat greater detail below.

The resentment hypothesis fared somewhat better - the interaction between perceptions of gay wealth and negative character beliefs about gays significantly negatively predicted support in the non-student sample. While this relationship was not significant in the combined sample, this might be a result of the lower salience of the gay affluence stereotype among that group, which did not allow the predicted interaction to emerge in this instance.

Finally, the system justification hypothesis also found some traction in the data. Just world belief was a significant predictor of lower support, as was the combination of this variable with positive-stereotypic heterosexism and perceptions of gay affluence. Finally, for those participants who were particularly high in just world belief, perceiving gays as wealthy was significantly correlated with the belief that discrimination against gays is no longer an issue in our country.

For these high believers, gay affluence ratings were also more strongly associated with positive character beliefs about gays, and greater positive-stereotypic views about gays. Thus it seems that people high in just world belief take quite a different path to low support for pro-gay legal reform than that discussed in connection with the resentment hypothesis. Rather than believing gays lack the character traits that make them deserving of wealth, and justifying low support through resentment, these people, to the extent they view gays as wealthy, instead have stronger positive character views of gays, and are 
significantly more likely to endorse other positive stereotypes about gays, but believe that discrimination is no longer an issue. One could argue that instead of 'victim derogation', they have taken the alternate 'victim enhancement' route to system justification described by Kay, Jost and Young (2005).

My results, therefore, are generally consistent with those of Feather and Sherman (resentment is a better predictor of antipathy than envy) and of Kay, Jost and colleagues (positive stereotypes work to justify systemic inequalities for people high in just world belief). These findings are not only relevant to heterosexism research, but also to the areas of 'underdog support' and 'positive stereotype' research more broadly.

There were, however, two surprising results that were somewhat contradictory to past literature: the counter-intuitive relationships of race and participant income to support for pro-gay legal reform. In the current investigation, the contrast code for race which contrasted blacks (1) with all other identifications (0) positively predicted support. Lower income also positively predicted support in the combined sample. This contradicts past research which has found that blacks and people at lower income levels tend to be more homophobic. Of course, it is important to note that support for gay civil rights and homophobia are distinct concepts, and the studies which previously established links with race and income were only looking at the latter. It may be that despite whatever personal antipathy blacks and lower income individuals may feel for gays, they still are motivated by a general concern for civil equality.

Examining the zero-order correlations of race and income with homophobia and support side by side was revealing. While income on its own did not show a relationship at the bivariate level either with homophobia or support, race (once again, coded as 0 for 
non-black and 1 for black) was significantly positively correlated with homophobia, but its negative correlation with support was non-significant. This seems consistent with the logic expressed above. Even though blacks were, overall, more homophobic, this did not result in significantly lower support of legal rights for gays. Once the variance attributable to homophobia was accounted for, the relationship between black ethnicity and support actually became a positive one.

\section{Limitations}

Obtaining a large non-student sample proved to be a much slower and more difficult process than was anticipated. While I was ultimately able to recruit 175 nonSona participants (a figure which does not include the many potential participants who navigated to the survey but did not answer any questions, or who completed only the first page or two), in the end only 127 of these had data of sufficient completeness and could reliably be considered (heterosexual) non-students. Fortunately, this lack did not too greatly hinder the testing of my hypotheses, but considering the significant difference in perceptions of gay affluence between the student and non-student sample, it would have been desirable to have a non-student sample large enough to confidently assuage statistical power concerns.

Another issue is the lack of representativeness of the obtained sample (both student and non-student). In terms of race and ethnicity, the sample actually mirrors the United States population rather well (63\% White, 15\% Black, 11\% Hispanic, 4\% Asian, etc.), however, responses to the political orientation question revealed that the total sample was somewhat left of center, with only $26 \%$ indicating conservative leanings (responses of 5, 6 or 7). The total sample was also a good deal more supportive of gay 
rights $(M=5.13$ on a $1-7$ scale), including national legalization of gay marriage ( $M=$ 4.90), then would have been expected from a representative sample of the U.S. population. This range restriction may have weakened or obscured some of the relationships under investigation.

\section{Future Directions}

Having established the link between perceptions of gay affluence and lower support for pro-gay legal reform, the next logical step is to attempt manipulation of the descriptive norm of gay wealth, and see if levels of support for pro-gay legal reform fluctuate as a result.

Participants could be randomly assigned to either a myth-confirming or mythrefuting condition. In the myth-confirming condition, participants would be given an article articulating the gay affluence myth as fact (for instance, a marketing propaganda memo encouraging a corporation to take gays into account when designing their business model, due to gays' strong buying power). Participants in the myth-refuting condition would receive an excerpt from an article debunking the stereotype that gays are generally wealthy, and stressing the socioeconomic diversity of the GLBT community (for instance, Badgett's 1998 report published by the National Gay and Lesbian Task Force).

Next, participants would be given the legal reform questionnaire used in the current investigation. If the perception of gay affluence is manipulable, then it would be predicted (holding all other pertinent variables equal) that those assigned to the myth confirming condition would show significantly lower levels of support than participants in the myth refuting condition. If this turns out to be the case, this could have very profound implications for gay activism aimed at influencing popular opinion. The 
message these activists would need to communicate in order to take advantage of this manipulable norm may be in contradiction to the homonormative image the mainstream gay movement has tried to project in recent years. Still, it could provide a guidepost for how to frame the issue of gay equality in a way that may be less alienating to the broader American public.

Another avenue to pursue would be to take the dependent measure out of the realm of the hypothetical somewhat. I was surprised at the apparently high levels of support for pro-gay legal reform, and while part of that might be explainable by the slight liberal skew of the current sample, it might also be attributable to a social desirability bias. If instead of merely asking participants how supportive they 'would' be of a given legal reform, the methodology instead asked participants to sign a petition or agree to add their name to a letter to their local representative in support of the measures, the results might look quite different. How this would influence the relationship between support and perceptions of gay affluence (not to mention the other variables) is uncertain, but it would enhance the ecological validity of the findings.

Finally, the current investigation treated gays as an undivided group, which was desirable as a first approach - however it would be useful to determine to what extent the current results were driven by an interpretation bias of the word 'gays'. That is, when participants read that word, did a particular image come to mind? And if so, was that image of a white, gay male? Would the results be replicated if lesbians were specifically mentioned (e.g., rephrasing the materials to refer to "gay men and lesbians") or, alternatively, if they were the sole group referred to? 
In summary, the current work is a good first step toward unraveling the issue of why some people are still so adamantly opposed to legal equality for gays, but a great deal remains to be explored. It is hoped that this work can serve as a foundation for a program of research that will ultimately benefit pro-gay legal advocacy groups by helping them to refine the messages they communicate to the public, and build toward a more egalitarian future. 


\section{References}

Aiken, L. S., \& West, S. G. (1991). Multiple regression: Testing and interpretation interactions. Thousand Oaks, CA: Sage.

Badgett, M. V. L. (1998). Income Inflation: The Myth of Affluence Among Gay, Lesbian and Bisexual Americans. Policy Institute of the National Gay and Lesbian Task Force, with The Institute for Gay and Lesbian Studies. Available at: http://www.thetaskforce.org/downloads/reports/reports/IncomeInflationMyth .pdf.

Barrett, D. C., Pollack, L. M., Tilden, M. L. (2002). Teenage Sexual Orientation, Adult Openness, and Status Attainment in Gay Males. Sociological Perspectives, 45, 163-182.

Battle, J. \& Lemelle, A. J. (2002). Gender Differences in African American Attitudes Toward Gay Males. The Western Journal of Black Studies, 26, 134-139.

Bonilla, L., \& Porter, J. (1990). A comparison of Latino, Black, and non-Hispanic White attitudes toward homosexuality. Hispanic Journal of Behavioral Sciences, 12, 437-452.

Bouton, R., Gallaher, P., Garlinghouse, P., \& Leal, T. (1987). Scales for measuring fear of AIDS and homophobia. Journal of Personality Assessment, 51(4), 606-614.

Brigham, N. L., Kelso, K. A., Jackson, M. A., \& Smith, R. H. (1997). The roles of invidious comparison and deservingness in sympathy and schadenfreude. Basic and Applied Social Psychology, 19, 363-380. 
Cattell, R. B., \& Jaspers, J. (1967). A general plasmode for factor analytic exercises and research. Multivariate Behavioral Research Monographs, 3, 1-212.

Champoux, J. E., \& Peters, W. S. (1987). Form, effect size and power in moderated regression analysis. Journal of Occupational Psychology, 60, 243-255.

Durell, M., Chiong, C., \& Battle, J. (2007). Race, gender expectations, and homophobia: A quantitative exploration. Race, Class \& Gender. 14, 299-317.

Employment Non-Discrimination Act of 1994: Hearings on S. 2238 Before the Senate Comm. on Labor and Human Resources, 103d Cong. 703 (1994), statement of Joseph Broadus, Family Research Council.

Ender, P. 2006. Parallel analysis for pca and factor analysis. UCLA: Academic Technology Services, Statistical Consulting Group. http://www.ats.ucla.edu/stat/stata/ado/analysis/.

Feather, N. T., \& Sherman, R. (2002). Envy, resentment, schadenfreude, and sympathy: Reactions to deserved and undeserved achievement and subsequent failure. Personality and Social Psychology Bulletin, 28, 953-961.

Gorsuch, R. L. (1983). Factor analysis ( $2^{\text {nd }}$ ed.). Hillsdale, NJ: Lawrence Erlbaum. Gross, L. (2001). Up from invisibility: Lesbians, gay men, and the media in America. New York: Columbia University Press.

Hayton, J. C., Allen, D. G., \& Scarpello, V. (2004). Factor retention decisions in exploratory factor analysis: A tutorial on parallel analysis. Organizational Research Methods, 7, 191-205.

Jost, J. T., \& Burgess, D. (2000). Attitudinal ambivalence and the conflict between group and system justification motives in low status groups. Personality and Social 
Psychology Bulletin, 26, 293-305.

Jost, J. T., \& Hunyady, O. (2002). The psychology of system justification and the palliative function of ideology. European Review of Social Psychology, 13, 111153.

Jost, J. T., \& Kay, A. C. (2005). Exposure to benevolent sexism and complementary gender stereotypes: Consequences for specific and diffuse forms of system justification. Journal of Personality and Social Psychology, 88, 498-509.

Kay, A. C., \& Jost, J. T. (2003). Complementary justice: Effects of "poor but happy" and "poor but honest" stereotype exemplars on system justification and implicit activation of the justice motive. Journal of Personality and Social Psychology, 85, 823-837.

Kay, A. C., Jost, J. T., \& Young, S. (2005). Victim derogation and victim enhancement as alternate routes to system justification. Psychological Science, 16, 240-246.

Kennedy, M., \& Gorzalka, B. (2002). Asian and non-Asian attitudes toward rape, sexual harassment, and sexuality. Sex Roles, 46, 227-238

Lerner, M. J. (2003). The justice motive: Where social psychologists found it, how they lost it, and why they may not find it again. Personality and Social Psychology Review, 7, 388-399.

Lewis, G. B. (2003). Black-White differences in attitudes towards homosexuality and gay rights. Public Opinion Quarterly, 67, 59-78.

Lipkus, I. (1991). The construction and preliminary validation of a global belief in a just world scale and the exploratory analysis of the multidimensional belief in a just world scale. Personality and Individual Differences, 12, 1171-1178. 
Lord, F.M. (1980). Applications of item response theory to practical testing problems. New York: Erlbaum Associates.

Malcomnson, K. M., Christopher, A. N., Franzen, T., \& Keyes, B. J. (2006). The Protestant work ethic, religious beliefs, and homonegative attitudes. Mental Health, Religion and Culture, 9, 435-447.

Mirels, H. L., \& Garrett, J. B. (1971). The Protestant ethic as a personality variable. Journal of Consulting and Clinical Psychology, 36, 40-44.

Romer v. Evans, 517 U.S. 620, at 645-46, Scalia, J. dissenting (1996).

Romero, A. P., Baumle, A. K., Badgett M. V. L. \& Gates, G. J. (2007). United States Census Snapshot. The Williams Institute: Policy Studies Publications, UCLA School of Law, available at: http://www.law.ucla.edu/williamsinstitute/ publications/USCensusSnapshot.pdf.

Rubin, Z., \& Peplau, L. A. (1975). Who believes in a just world? Journal of Social Issues, 31, 65-90.

Salovey, P. \& Rodin J. (1984). Some Antecedents and Consequences of SocialComparison Jealousy. Journal of Personality and Social Psychology, 47, 780792.

Soule, T. (2006, April). The myth of gay affluence. Orange County Blade, 12-17.

StataCorp. 2005. Stata Statistical Software: Release 9. College Station, TX: StataCorp LP.

Vandello, J. A., Goldschmied, N. P., \& Richards, D. A. R. (2007). The Appeal of the Underdog. Personality and Social Psychology Bulletin, 33, 1603-1616.

Waldner, L. K., Sikka, A., \& Baig, S. (1999). Ethnicity and sex differences in university 
students' knowledge of AIDS, fear of AIDS, and homophobia. Journal of Homosexuality, 37, 117-133.

Walls, N. E. (2008a). Modern heterosexism and social dominance orientation: Do subdomains of heterosexism function as hierarchy-enhancing legitimizing myths? In T. G. Morrison \& M. A. Morrison, The Psychology of Modern Prejudice (p. 225-259). Hauppauge, NY: Nova Science Publishers.

Walls, N. E. (2008b). Toward a multidimensional understanding of heterosexism: The changing nature of prejudicial attitudes. Journal of Homosexuality, 55, 20-70.

Walls, N. E. (2009). Grappling with the relationship between men's endorsement of positive stereotypes of women and support for women's rights. In V. Demos \& M. T. Segal (Eds.), Advances in Gender Research, 13, 81-112. (pre-print pdf available at: https://portfolio.du.edu/portfolio/getportfoliofile?uid=109496).

Weinberg, D. H. (2004). Evidence From Census 2000 About Earnings by Detailed Occupation for Men and Women. Census 2000 Special Reports, U.S. Census Bureau, available at: http://www.census.gov/prod/2004pubs/censr-15.pdf. 
Appendices 


\section{Appendix A - Informed Consent Statement for Sona Recruits}

You are being asked to participate in a study hosted by the University of South Florida Psychology Department. The purpose of this study is to examine beliefs about relative wealth of different groups, and also more general beliefs about the way the world works. You will be asked to fill out a questionnaire which will solicit your responses in these areas.

The questionnaire has been reviewed and approved by the University's Institutional Review Board. Completing the questionnaire is very easy and should take no more than 30 minutes. You will be asked to complete questions about the concepts described above, as well as limited demographic information.

You will receive one credit toward your research participation requirement if you complete the questionnaire. Completion of the questionnaire is completely voluntary. If you feel uncomfortable with a question, you may skip that question and go to the next one or withdraw from the questionnaire completely. However, if you withdraw from the study completely before finishing it, you will not receive credit for your participation.

There is an option to receive an ADDITIONAL RESEARCH CREDIT, by recruiting a non-student friend, family member or acquaintance to complete the questionnaire. If you are interested in this extra credit option, please let the researcher know, so that he/she can give you more details once you have completed the questionnaire.

There are no known risks involved in completing the questionnaire. By participating you are increasing our knowledge and understanding of group level beliefs. Your responses will be kept confidential to the extent of the law. Authorized personnel may inspect the records from this research project. However, because the questionnaire is completely anonymous, anyone who inspects the records will NOT be able to identify you personally. The data obtained from the questionnaire will be kept in a secure location and will be available only to the individual researchers who are in charge of the study.

If you have questions about your rights as a person who is taking part in a research study, you may contact a member of the Division of Research Compliance of the University of South Florida at 813-974-5638. If you have any other questions about your participation, please feel free to contact Vanessa Hettinger at vhetting@mail.usf.edu, or Joseph Vandello at vandello@cas.usf.edu.

By indicating to the researcher that you want to proceed, you agree that you understand that you are being asked to participate in research, you understand the risks and benefits, and freely consent to participate in the current research project under the conditions described.

Thank you! 


\section{Appendix A (Continued) - Informed Consent Statement for Non-Sona Recruits}

You are being asked to participate in a study hosted by the University of South Florida Psychology Department. The purpose of this study is to examine beliefs about relative wealth of different groups, and also more general beliefs about the way the world works. You will be asked to fill out several questionnaires which will solicit your responses in these areas. If you are under 18 years old, you cannot take part in this study.

The questionnaire has been reviewed and approved by the University's Institutional Review Board. Completing the questionnaire is very easy and should take no more than 30 minutes. You will be asked to complete questions about the concepts described above, as well as limited demographic information.

If you are completing the questionnaire on behalf of a USF student, the student who asked you to complete this questionnaire will receive one credit toward his or her research participation requirement if you complete the questionnaire. Completion of the questionnaire is completely voluntary. If you feel uncomfortable with a question, you may skip that question and go to the next one or withdraw from the questionnaire completely. However, if you withdraw from the study completely before finishing it, your student acquaintance will not receive credit for your participation.

There are no known risks involved in completing the questionnaire. By participating you are increasing our knowledge and understanding of group level beliefs. Your responses will be kept confidential to the extent of the law. Authorized personnel may inspect the records from this research project. However, because the questionnaire is completely anonymous, anyone who inspects the records will NOT be able to identify you personally. The data obtained from the questionnaire will be kept in a secure location and will be available only to the individual researchers who are in charge of the study.

If you have questions about your rights as a person who is taking part in a research study, you may contact a member of the Division of Research Compliance of the University of South Florida at 813-974-5638. If you have any other questions about your participation, please feel free to contact Vanessa Hettinger at vhetting@mail.usf.edu, or Joseph Vandello at vandello@cas.usf.edu.

By continuing to the questionnaire you affirm that you are at least 18 years old, and that you understand that you are being asked to participate in research, you understand the risks and benefits, and freely consent to participate in the current research project under the conditions described.

Thank you!

1) If you are completing the questionnaire on behalf of a USF student, please enter the 3-digit identifier you were given in the space provided. 


\section{Appendix A (Continued) - Optional Credit Instructions}

Thank you for electing to participate in the additional credit option. In order to fully test our hypotheses, we want to compare students' responses to responses from nonstudents. In order to collect a non-student sample, we are enlisting your help. We would like you to choose someone you know who is a non-student adult (at least 18, preferably over 30) to complete the questionnaires you just completed. The person you choose can be a family member, a friend, a coworker, or anyone you know, as long as they are over 18 and are not a student.

In order to receive the additional credit, simply direct your recruit to the website below, where they can complete the survey. You have been assigned a unique 3-digit identifier; inform your recruit that they must enter your 3-digit identifier on the first page of the survey, and that they must complete and submit the survey in one sitting. Once they submit their survey, the number they enter will be checked against our log, and you will receive credit. Your recruit must complete and submit the survey by or before the morning of April $16^{\text {th }}, 2010$ in order for you to receive credit.

\section{Please note:}

It is very important that your recruit's participation is completely voluntary. You must not force or unfairly induce your recruit to complete the survey.

Do not discuss the content of the questionnaire with your recruit until after he/she has completed and submitted it. Refrain from discussing your thoughts about the survey or opinions regarding the hypotheses of the research, or any other statements that might have the potential to bias your recruit's responses. If asked, you may tell them that the study pertains to 'beliefs about wealth and legal reforms', but do not share anything else.

Be sure to give your recruit your 3-digit identifier; without that, you cannot get credit!

If you have any questions, feel free to email Vanessa Hettinger (vhetting@mail.usf.edu).

Survey website: $\mathrm{http} / /$ www.surveygizmo.com/s/257770/wealth-and-legal-reform

\section{Your 3-digit identifier:}




\section{Appendix B - Materials}

\section{Relative Affluence Questionnaire:}

2008 census statistics indicate that the median income for individuals in the U.S. who are working full time year-round is approximately $\$ 42,000$ / year. The average household income in the U.S. is approximately $\$ 50,000$ / year. Bearing these statistics in mind, for each of the five demographic groups listed below, please indicate how wealthy you perceive each group generally to be, using the scale provided.

\begin{tabular}{|c|c|c|c|c|c|}
\hline & $\begin{array}{c}\text { Much less } \\
\text { wealthy } \\
\text { than the } \\
\text { average } \\
\text { American }\end{array}$ & $\begin{array}{c}\text { Somewhat } \\
\text { less } \\
\text { wealthy } \\
\text { than the } \\
\text { average } \\
\text { American }\end{array}$ & $\begin{array}{c}\text { About as } \\
\text { wealthy } \\
\text { as the } \\
\text { Average } \\
\text { American }\end{array}$ & $\begin{array}{c}\text { Somewhat } \\
\text { more } \\
\text { wealthy } \\
\text { than the } \\
\text { average } \\
\text { American }\end{array}$ & $\begin{array}{c}\text { Much } \\
\text { more } \\
\text { wealthy } \\
\text { than the } \\
\text { average } \\
\text { American }\end{array}$ \\
\hline Gays: & & & & & \\
\hline $\begin{array}{l}\text { African- } \\
\text { Americans / } \\
\text { Carribeans: }\end{array}$ & & & & & \\
\hline Hispanics: & & & & & \\
\hline Jews: & & & & & \\
\hline Republicans: & & & & & \\
\hline
\end{tabular}

\section{Own Affluence Questionnaire:}

Now please answer the same question, but rate your own household. For instance, you should consider your parents' combined income if you are still classified as a dependent, your individual income if living independently, or your income combined with your spouse's income if married. If you are unsure, select the option that most nearly captures the economic status in which you have lived for the majority of your life.

\begin{tabular}{|c|c|c|c|c|}
\hline $\begin{array}{c}\text { Much less } \\
\text { wealthy than } \\
\text { the average } \\
\text { American } \\
\text { household }\end{array}$ & $\begin{array}{c}\text { Somewhat } \\
\text { less } \\
\text { wealthy } \\
\text { than the } \\
\text { average } \\
\text { American } \\
\text { household }\end{array}$ & $\begin{array}{c}\text { About as } \\
\text { wealthy } \\
\text { as the } \\
\text { Average } \\
\text { American } \\
\text { household }\end{array}$ & $\begin{array}{c}\text { Somewhat } \\
\text { more } \\
\text { wealthy } \\
\text { than the } \\
\text { average } \\
\text { American } \\
\text { household }\end{array}$ & $\begin{array}{c}\text { Much } \\
\text { more } \\
\text { wealthy } \\
\text { than the } \\
\text { average } \\
\text { American } \\
\text { household }\end{array}$ \\
\hline
\end{tabular}




\section{Appendix B-Materials (continued)}

\section{Character Beliefs Questionnaire:}

For each of the five demographic groups listed below, there are eight trait pairs. For each trait pair, please select the option from the drop-down menu that most closely represents where you believe that demographic group generally falls along that dimension. Be sure to scroll over and select a response for all trait pairs.

\begin{tabular}{|c|l|l|l|l|l|l|l|l|c|}
\hline Lazy & & & & & & & & & Hardworking \\
\hline Dedicated & & & & & & & & & Uncommitted \\
\hline $\begin{array}{c}\text { Well- } \\
\text { educated }\end{array}$ & & & & & & & & & Ignorant \\
\hline Poor & & & & & & & & & Rich \\
\hline Stupid & & & & & & & & & Intelligent \\
\hline Creative & & & & & & & & & Unimaginative \\
\hline Persevering & & & & & & & & & Wavering \\
\hline Dishonest & & & & & & & & & Honest \\
\hline
\end{tabular}

Now please consider the same eight trait pairs again, but rate yourself along each dimension. Be sure to scroll over and select a response for all trait pairs.

\begin{tabular}{|c|l|l|l|l|l|l|l|l|c|}
\hline Lazy & & & & & & & & & Hardworking \\
\hline Dedicated & & & & & & & & & Uncommitted \\
\hline $\begin{array}{c}\text { Well- } \\
\text { educated }\end{array}$ & & & & & & & & & Ignorant \\
\hline Poor & & & & & & & & & Rich \\
\hline Stupid & & & & & & & & & Intelligent \\
\hline Creative & & & & & & & & & Unimaginative \\
\hline Persevering & & & & & & & & & Wavering \\
\hline Dishonest & & & & & & & & & Honest \\
\hline
\end{tabular}




\section{Appendix B-Materials (continued)}

\section{Screen capture of Character Beliefs Questionnaire:}

For each of the five demographic groups listed below, there are eight trait pairs. For each trait pair, please select the option from the drop-down menu that most closely represents where you believe that demographic group generally falls along that dimension. Be sure to scroll over and select a response for all trait pairs.

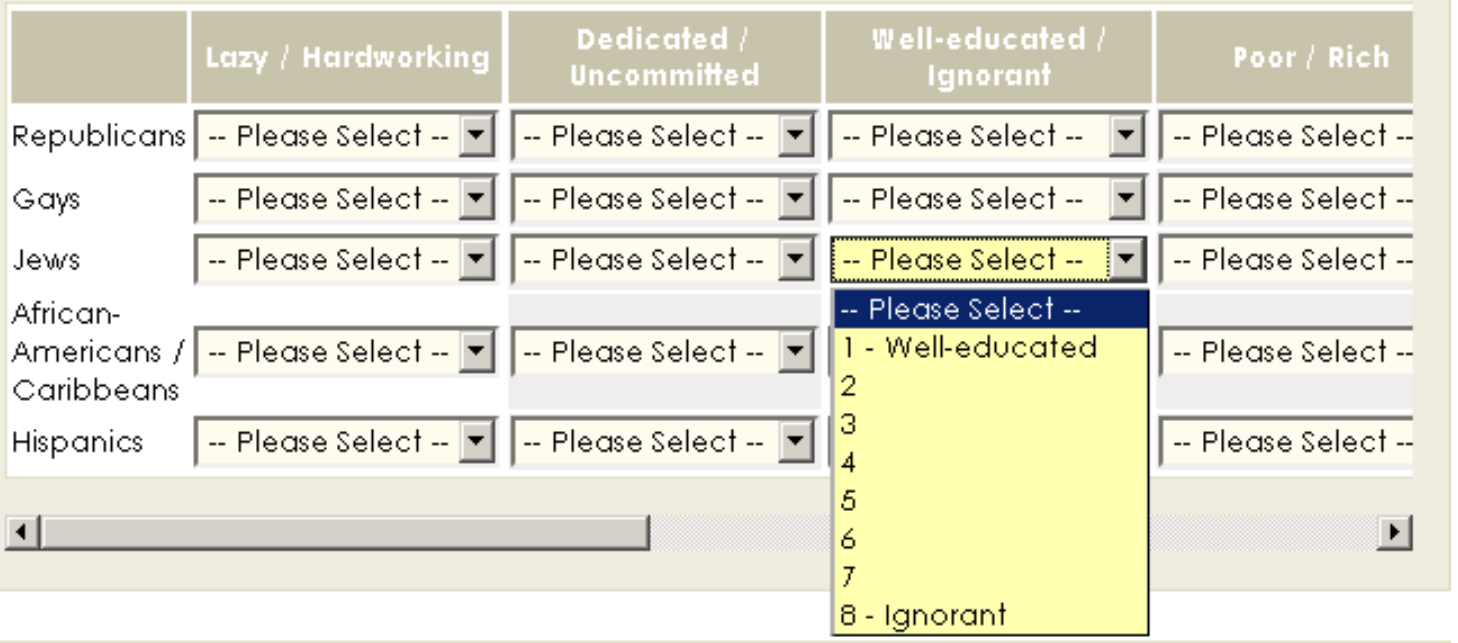

Now please consider the same eight trait pairs again, but rate yourself along each dimension.

Be sure to scroll over and select a response for all trait pairs.

\begin{tabular}{|c|c|c|c|c|c|}
\hline & Lazy / Hardworking & $\begin{array}{l}\text { Dedicated / } \\
\text { Uncommitted }\end{array}$ & $\begin{array}{l}\text { Wf ell-educated / } \\
\text { Ignorant }\end{array}$ & Poor / Rich & Stu \\
\hline Self: & -- Please Select -- - & -- Please Select -- & -- Please Select -- & -- Please Select -- - & $\overline{-P}$ \\
\hline
\end{tabular}




\section{Appendix B-Materials (continued)}

Protestant Work Ethic Scale (Mirels \& Garrett, 1971):

1) Most people spend too much time in unprofitable amusements.

2) Our society would have fewer problems if people had less leisure time.

3) Money acquired easily (e.g., through gambling or speculation) is usually spent unwisely.

4) There are few satisfactions equal to the realization that one has done his best at a job.

5) The most difficult college courses usually turn out to be the most rewarding.

6) Most people who don't succeed in life are just plain lazy.

7) The self-made man is likely to be more ethical than the man born to wealth.

8) I often feel I would be more successfully if I sacrificed certain pleasures.

9) People should have more leisure time to spend in relaxation.*

10) Any man who is able and willing to work hard has a good chance of succeeding.

11) People who fail at a job have usually not tried hard enough.

12) Life would have very little meaning if we never had to suffer.

13) Hard work offers little guarantee of success.*

14) The credit card is a ticket to careless spending.

15) Life would be more meaningful if we had more leisure time.*

16) The man who can approach an unpleasant task with enthusiasm is the man who gets ahead.

17) If one works hard enough he is likely to make a good life for himself.

18) I feel uneasy when there is little work for me to do.

19) A distaste for hard work usually reflects a weakness of character.

Global Belief in a Just World Scale Lipkus, 1991):

1) I feel that people get what they are entitled to have.

2) I feel that a person's efforts are noticed and rewarded.

3) I feel that people earn the rewards and punishments they get.

4) I feel that people who meet with misfortune have brought it on themselves.

5) I feel that people get what they deserve.

6) I feel that rewards and punishments are fairly given.

7) I basically feel that the world is a fair place.

Amnestic Heterosexism Subscale (Walls, 2008):

1) Gays are not treated as fairly as everyone else in today's society.

2) Most people treat gays as fairly as they treat everyone else.

3) Gays continue to face discrimination in the U.S.

4) Discrimination against gays is virtually non-existent in today's society. 
Appendix B-Materials (continued)

Positive Stereotypic Heterosexism Subscale (Walls, 2008):

1) Lesbians are better than heterosexual women at physically defending themselves.

2) Gay men take better care of their bodies than do heterosexual men.

3) Gay men are more compassionate than heterosexual men.

4) Lesbians excel at outdoor activities more than heterosexual women.

Homophobia Scale (Bouton, Gallaher, Garlinghouse and Leal, 1987):

1) Homosexuals contribute positively to society*

2) Homosexuality is disgusting.

3) Homosexuals are just as moral as heterosexuals.*

4) Homosexuals should have equal civil rights.*

5) Homosexuals corrupt young people.

6) Homosexuality is a sin.

7) Homosexuality should be against the law.

Legal Reform Questionnaire:

1) How supportive would you be of a policy change which would allow gays to serve openly in the U.S. military?

2) How supportive would you be of a change in national law which would allow gays to marry in every state?

3) How supportive would you be of a law in your state allowing gays to marry?

4) How supportive would you be of a change in national law which would officially recognize the marriages of gays whose marriages are legally recognized in their own state?

5) How supportive would you be of a national law which would allow gays to adopt children in every state?

6) How supportive would you be of a law in your state allowing gays to adopt children?

7) How supportive would you be of a national law which would include gays as a protected group for purposes of employment discrimination?

8) How supportive would you be of a law in your state which would include gays as a protected group for purposes of employment discrimination?

9) How supportive would you be of a national law which would include gays as a protected group for all existing hate crimes legislation?

10) How supportive would you be of a law in your state which would include gays as a protected group for all existing hate crimes legislation? 
Appendix B-Materials (continued)

Demographics Questionnaire:

Thank you for completing the questionnaires. Please take a moment to complete the following personal information:

Sex: Male Female

Age

What is your racial/ethnic heritage?

1) White / Anglo or European American (non-Hispanic)

2) Black / African American / Caribbean

3) Hispanic / Latino(a)

4) Asian / Pacific Islander

5) Indian / South Asian

6) Arab / Middle Eastern

7) Other

Are you a student? Yes No

If so, what is your year in college? [If no, leave this question blank.]:

\begin{tabular}{|l|l|l|l|l|l|}
\hline 1 & 2 & 3 & 4 & 5 & 6 or more \\
\hline
\end{tabular}

Please circle the number from the scale below that best describes your sexual orientation:

\begin{tabular}{|c|c|c|c|c|c|c|}
\hline 1 & 2 & 3 & 4 & 5 & 6 & 7 \\
\hline $\begin{array}{c}\text { Exclusively } \\
\text { heterosexual } \\
\text { (straight) }\end{array}$ & & & & & & $\begin{array}{c}\text { Exclusively } \\
\text { homosexual } \\
\text { (gay) }\end{array}$ \\
\hline
\end{tabular}

Do you have a religious preference? $\mathrm{Y} N$

If yes, which denomination? [If you selected 'no', please enter 'N/A' here.] 


\section{Appendix B-Materials (continued)}

How strongly do you identify with the denomination listed above? (If 'N/A', please select zero from the scale below.)

\begin{tabular}{|c|c|c|c|c|c|}
\hline 0 & 1 & 2 & 3 & 4 & 5 \\
\hline $\begin{array}{c}\text { Identify in } \\
\text { name only }\end{array}$ & $\begin{array}{c}\text { Very } \\
\text { weakly } \\
\text { identified }\end{array}$ & $\begin{array}{c}\text { Somewhat } \\
\text { weakly } \\
\text { identified }\end{array}$ & $\begin{array}{c}\text { About } \\
\text { average }\end{array}$ & $\begin{array}{c}\text { Somewhat } \\
\text { strongly } \\
\text { identified }\end{array}$ & $\begin{array}{c}\text { Very } \\
\text { strongly } \\
\text { identified }\end{array}$ \\
\hline
\end{tabular}

How often do you attend church or your place of worship? (If 'N/A', please select 'never'.)

\begin{tabular}{|c|c|c|c|c|c|}
\hline 0 & 1 & 2 & 3 & 4 & 5 \\
\hline Never & $\begin{array}{c}\text { Less than } \\
\text { once a year }\end{array}$ & $\begin{array}{c}\text { About once } \\
\text { a year }\end{array}$ & $\begin{array}{c}\text { About once } \\
\text { a month }\end{array}$ & $\begin{array}{c}\text { Nearly } \\
\text { every week }\end{array}$ & Every week \\
\hline
\end{tabular}

How would you describe your political orientation:

$\begin{array}{lllllllll}\text { Very Liberal } & 1 & 2 & 3 & 4 & 5 & 6 & 7 & \text { Very Conservative }\end{array}$

What is your parents' approximate household income, or your own household income if living independently? (If you are unsure, select the option that most nearly captures the economic status in which you have lived for the majority of your life.)

1) under $\$ 20,000$

2) $\$ 20,000-\$ 30,000$

3) $\$ 30,000-\$ 40,000$

4) $\$ 40,000-\$ 50,000$

5) $\$ 50,000-\$ 60,000$

6) $\$ 60,000-\$ 70,000$

7) $\$ 70,000-\$ 80,000$

8) $\$ 80,000-\$ 90,000$
9) $\$ 90,000-\$ 100,000$

10) $\$ 100,000-\$ 110,000$

11) $\$ 110,000-\$ 120,000$

12) $\$ 120,000-\$ 130,000$

13) $\$ 130,000-\$ 140,000$

14) $\$ 140,000-\$ 150,000$

15) $\$ 150,000$ or greater 


\begin{abstract}
About the Author
Vanessa Hettinger graduated from Amherst College with a B.A. in English and a B.A. with honors in Psychology. She received the Amherst College Stonewall Prize for her undergraduate thesis entitled "Effects of Heterosexism and Gender Stereotyping in Constructive Memory". She entered Harvard Law School in 2005, and was awarded the Harvard Gay and Lesbian Alumni Committee Summer Fellowship to help fund her work as a legal intern for the Gay and Lesbian Advocates and Defenders in 2006. She received her J.D. in 2008 before entering the Psychology PhD program at the University of South Florida where she is a member of the Cognition, Neuroscience and Social area, with a focus on social psychology.
\end{abstract}

